\title{
Ordovician klippen structures of the Sierra de Umango: New insights on Tectonic evolution of the Western Sierras Pampeanas, Argentina
}

\author{
Vinícius Tieppo Meira ${ }^{\mathrm{a}, *}$, Mario da Costa Campos Neto ${ }^{\mathrm{a}}$, Pablo Diego González ${ }^{\mathrm{b}}$, \\ Miguel Ângelo Stipp Basei ${ }^{a}$, Ricardo Varela ${ }^{b}$ \\ a Instituto de Geociências, Universidade de São Paulo, Rua do Lago 562, 05508-080 São Paulo-SP, Brazil \\ ${ }^{\mathrm{b}}$ CONICET - Centro de Investigaciones Geológicas, Universidad Nacional de La Plata, Calle 1 \#644, B1900TAC La Plata, Argentina
}

\section{A R T I C L E I N F O}

\section{Article history:}

Received 16 May 2011

Accepted 21 February 2012

\section{Keywords}

Western Gondwana

Central Andes

Cuyania terrane

Western Sierras Pampenas

Umango

Structural evolution

\begin{abstract}
A B S T R A C T
The basement rock of the Pampean flat-slab (Sierras Pampeanas) in the Central Andes was uplifted and rotated in the Cenozoic era. The Western Sierras Pampeanas are characterised by meta-igneous rocks of Grenvillian Mesoproterozoic age and metasedimentary units metamorphosed in the Ordovician period. These rocks, known as the northern Cuyania composite terrane, were derived from Laurentia and accreted toward Western Gondwana during the Early Paleozoic. The Sierra de Umango is the westernmost range of the Western Sierras Pampeanas. This range is bounded by the Devonian sedimentary rocks of the Precordillera on the western side and Tertiary rocks from the Sierra de Maz and Sierra del Espinal on the eastern side and contains igneous and sedimentary rocks outcroppings from the Famatina System on the far eastern side.

The Sierra de Umango evolved during a period of polyphase tectonic activity, including an Ordovician collisional event, a Devonian compressional deformation, Late Paleozoic and Mesozoic extensional faulting and sedimentation (Paganzo and Ischigualasto basins) and compressional deformation of the Andean foreland during the Cenozoic.

A Nappe System and an important shear zone, La Puntilla-La Falda Shear Zone (PFSZ), characterise the Ordovician collisional event, which was related to the accretion of Cuyania Terrane to the proto-Andean margin of Gondwana. Three continuous deformational phases are recognised for this event: the D1 phase is distinguished by relics of S1 preserved as internal foliation within interkinematic staurolite porphyroblasts and likely represents the progressive metamorphic stage; the D2 phase exhibits P-T conditions close to the metamorphic peak that were recorded in an S2 transposition or a mylonitic foliation and determine the main structure of Umango; and the D3 phase is described as a set of tight to recumbent folds with S3 axial plane foliation, often related to thrust faults, indicating the retrogressive metamorphic stage. The Nappe System shows a top-to-the S/SW sense direction of movement, and the PFSZ served as a right lateral ramp in the exhumation process. This structural pattern is indicative of an oblique collision, with the Cuyania Terrane subducting under the proto-Andean margin of Gondwana in the NE direction. This continental subduction and exhumation lasted at least 30 million years, nearly the entire Ordovician period, and produced metamorphic conditions of upper amphibolite-to-granulite facies in medium- to high-pressure regimes.

At least two later events deformed the earlier structures: D4 and D5 deformational phases. The D4 deformational phase corresponds to upright folding, with wavelengths of approximately $10 \mathrm{~km}$ and a general $\mathrm{N}-\mathrm{S}$ orientation. These folds modified the $\mathrm{S} 2$ surface in an approximately cylindrical manner and are associated with exposed, discrete shear zones in the Silurian Guandacolinos Granite. The cylindrical pattern and subhorizontal axis of the D4 folds indicates that the S2 surface was originally flat-lying. The D4 folds are responsible for preserving the basement unit Juchi Orthogneiss synformal klippen. This deformation corresponds to the Chanica Tectonic during the interval between the Devonian and Carboniferous periods. The D5 deformational phase comprehends cuspate-lobate shaped open plunging folds with $\mathrm{E}-\mathrm{W}$ high-angle axes (D5 folds) and sub-vertical spaced cleavage. The D5 folds and related spaced cleavage deformed the previous structures and could be associated with uplifting during the Andean Cycle.
\end{abstract}

(c) 2012 Elsevier Ltd. All rights reserved.

\footnotetext{
* Corresponding author. Tel: + 551197752553.

E-mail address: viniciusgeologia@gmail.com (V.T. Meira).
} 


\section{Introduction}

The tectonic history of the basement of west-central Argentina is characterised by a Late Neoproterozoic-Early Cambrian Pampean orogenic cycle and an Ordovician Famatinian orogenic cycle. The latter is associated with the accretion of a Laurentian-derived microcontinent (Cuyania Terrane) to the southwestern protoAndean margin of Gondwana (Ramos, 1988a; Ramos et al., 1998, and synthesis in Thomas and Astini, 2003, Ramos, 2004), and both events are recorded in the Sierras Pampeanas. The Sierras Pampeanas are made up of igneous and metamorphic rocks uplifted and rotated during the Cenozoic by the compressive foreland tectonics of the Pampean flat-slab (Ramos et al., 2002).
Rocks of Mesoproterozoic age have been recognised along an $\mathrm{N}-\mathrm{S}$ trending belt (Fig. 1) that includes the Western Sierras Pampeanas (sensu Caminos, 1979) in the north and Las Matras block in the south (Sato et al., 2000). This belt is considered to be the basement of the Cuyania Terrane and includes the Toro Negro, Umango, Maz and Espinal Ranges in the north, the Pie de Palo range and surroundings in the central area, and the San Rafael and Las Matras blocks in the south (Sato et al., 2000, 2004 and references therein).

The Umango, Maz and Espinal Ranges, which are part of the Western Sierras Pampeanas, consist of meta-igneous and metasedimentary rocks, which are exposed between $28^{\circ} 45^{\prime}-29^{\circ} 30^{\prime} \mathrm{S}$ latitude and $68^{\circ} 50^{\prime}-68^{\circ} 15^{\prime} \mathrm{W}$ longitude in southwestern La Rioja

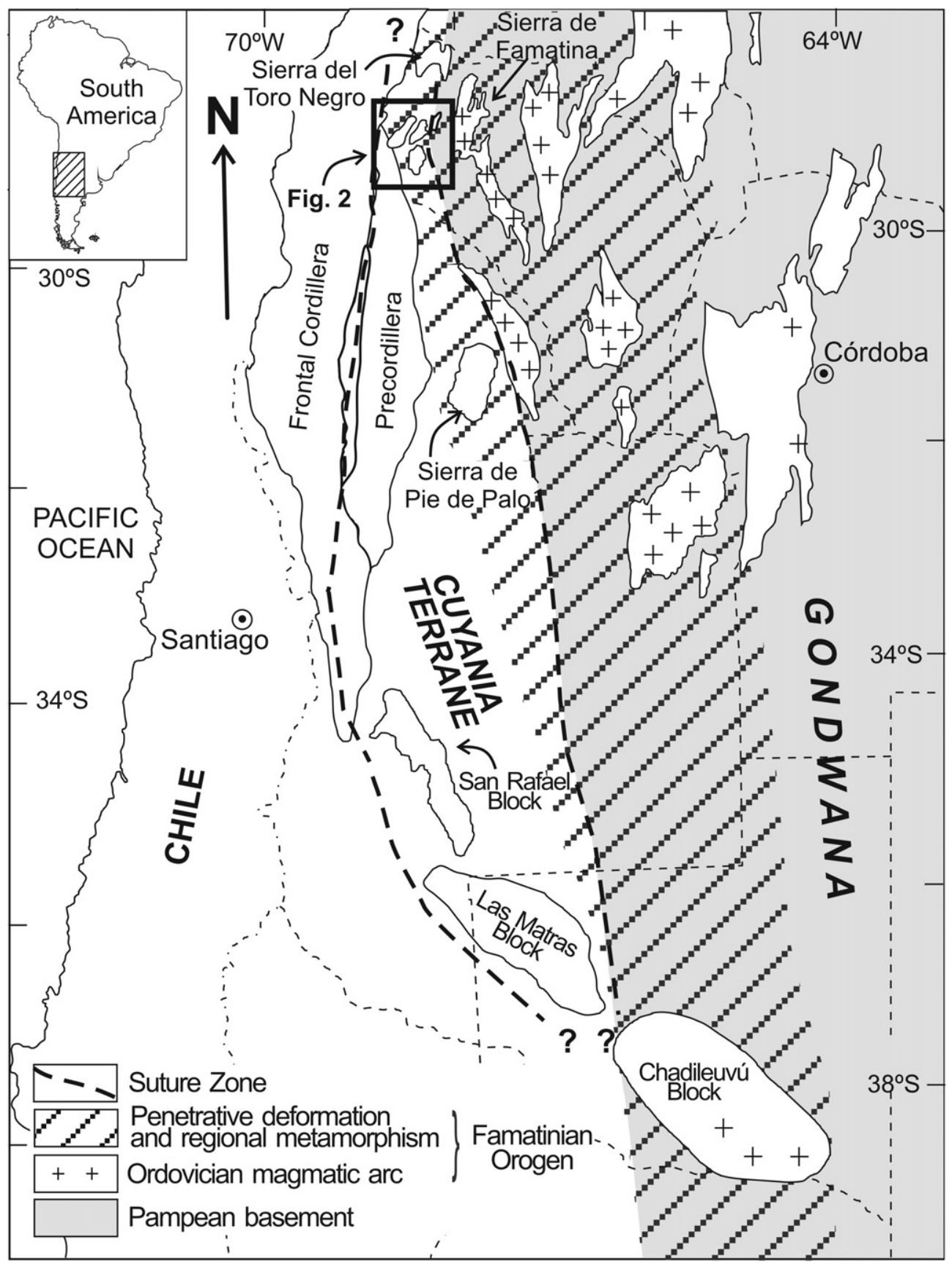

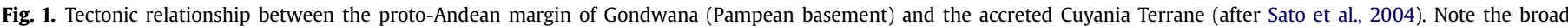

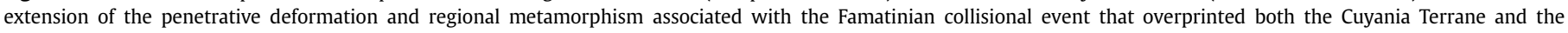
Gondwana border. The Ordovician magmatic arc intruded within the Pampean basement of the Gondwana margin. 
Province, Argentina. These units are bounded by Devonian sedimentary rocks (Punilla Formation) of the Precordillera Occidental in the west and by granitic, volcanic and sedimentary rocks of the Famatina System in the east (Fig. 2).

Since Hausen's (1921) first descriptions, the diversity of lithotypes and the structural complexity of the basement of the Sierra de Umango have been described by Furque (1972); more recently, geochemistry, geochronology (Varela et al., 1996, 2000, 2001, 2003a,b, 2008) and thermo-tectonic evolution (Porcher et al., 2004 and references therein) have revealed the history of this range. The geological units of the Sierra de Umango are summarised in Varela et al. (2008, 2011), but a more comprehensive overview of these units is required to improve the interpretations of available geochronological data. In fact, characterisations of deformational events, the metamorphic history and the relationships among geological units are essential to an improved understanding of the geodynamic history of the Famatinian orogenic belt.

The objectives of this contribution were to review the relationships between the geological units of the Sierra de Umango, to identify and describe their main structures and to explain the

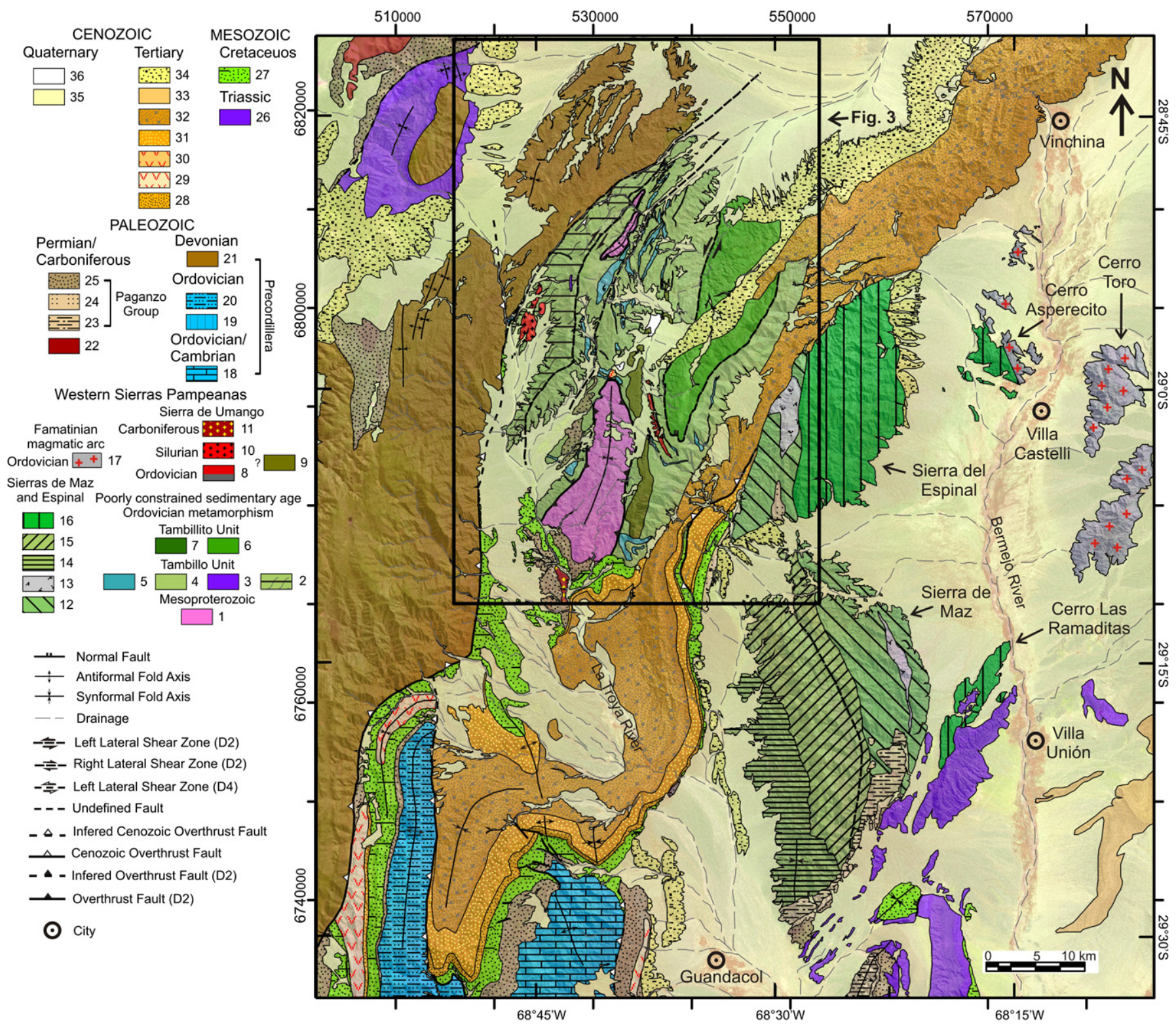

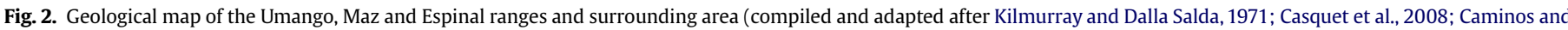

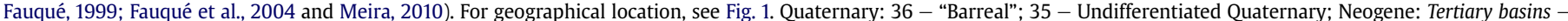

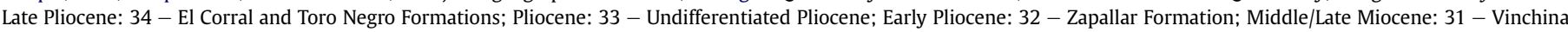

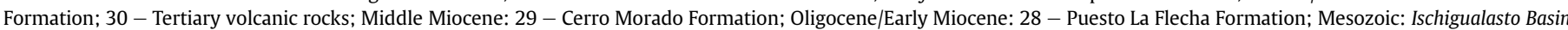

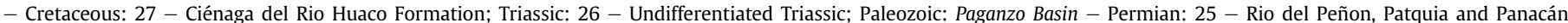

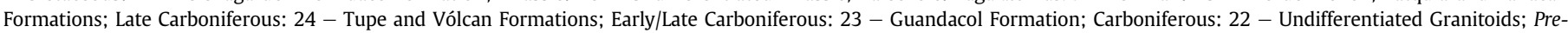

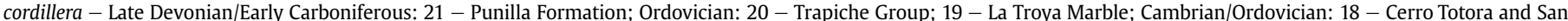

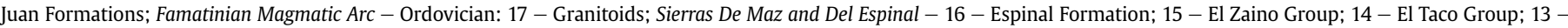

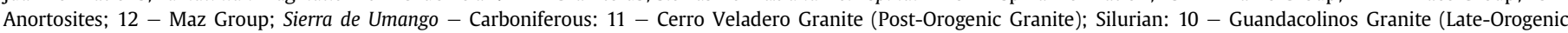

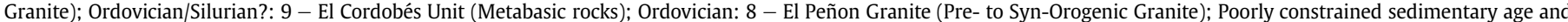

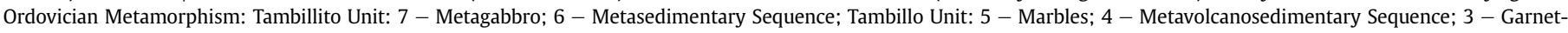
bearing metagabbro; 2 - Mylonites PFSZ; Estenian Mesoproterozoic: 1 - Juchi Orthogneiss. A color version of this figure is available in the online edition. 
relevant kinematic history. Geological mapping, petrography, and structural analysis were used to achieve these goals. Our new data (see below) suggest the development of a Nappe System (according to McClay and Price, 1981) with a top-to-the S/SW sense direction of movement and an important right lateral shear zone, La Puntilla-La Falda Shear Zone (PFSZ), that served as a lateral ramp in the shortening processes associated with the Ordovician oblique collisional event (Famatinian Orogeny) caused by accretion of the Cuyania Terrane with the proto-Andean margin of Gondwana (Meira, 2010 and Varela et al., 2011). The metamorphic conditions accompanying this event in this part of the Sierras Pampeanas fall up to the medium- to high-pressure regime of the upper amphibolite-to-granulite facies. Two post-collisional and diachronous events were identified: the Chanica Phase and the Andean Cycle in the Devonian-Carboniferous and Tertiary periods, respectively (Meira, 2010 and Varela et al., 2011).

\section{Geological overview}

Andean geological history has been extensively studied, and its complexity has been recognised, since the middle of the last century (e.g., Gansser, 1973; Coira et al., 1982; Ramos et al., 1986; Ramos, 1988a,b, 1999a,b; Ramos and Aleman, 2000). Morphological, structural and geological differences along the length of the Andes-Cordillera (8000-km long) led to the identification of three major sections: the Northern, Central and Southern Andes (Gansser, 1973).

Processes, such as accretion of "suspect" terrane, played an important geodynamic role in continental growth, and the principles of these processes were mainly described in the 1980s by Coney et al. (1980), Jones et al. (1983) and Howell (1989).

Paleozoic "suspect" terranes, which had docked along the western border of Gondwana in the Central Andes were first described by Ramos et al. (1984, 1986). Since then, many other geotectonic hypotheses involving accretion of "suspect" terranes have been suggested and their terrane boundaries have been outlined. Most of the proposed tectonic hypotheses involve an allochthonous (Laurentian) origin: 1. The Occidentalia Terrane was a large part of Laurentia and was left behind after continent-continent collision during the Neoproterozoic to Early/ Middle Paleozoic eras (Dalla Salda et al., 1992a,b; Dalziel et al., 1994); 2. The Cuyania, or Precordillera, Terrane was an independent smaller continental block that rifted away from Laurentia prior to collision with Gondwana during the Middle Ordovician (synthesis in Thomas and Astini, 2003 and Ramos, 2004) or Silurian/Devonian period (e.g., Keller et al., 1998; Pankhurst and Rapela, 1998; Rapela et al., 1998); and 3. An adjacent plateau (Keller, 1999), the Texas Plateau (Dalziel, 1997), attached as a promontory to Laurentia, was left behind after a short collision with Gondwana. The Chilenia Terrane was thought to be another smaller continental block that docked later during the Silurian or Devonian period (Ramos et al., 1998; Quernadelle and Ramos, 1999; Ramos, 1999b). In contrast to these exotic interpretations, Aceñolanza and Toselli (1988), Baldis et al. (1989), Aceñolanza et al. (2002) and Finney et al. (2003) proposed that the Cuyania Terrane had a paraautochthonous Gondwanan origin, situated in the same latitudinal belt as Laurentia to help explain the Precordillera carbonate platform and their palaeontology. These authors suggested that a strike-slip displacement moved the "SAFRAN" platform from the southern sector of Gondwana - between South America, Africa and Antarctica - to its present position. Although, the solely strike-slip accretion of the Cuyania Terrane is refuted by strong tectono-metamorphic evidences in the Sierra de Pie de Palo that the accretion involved subduction of the Iapetus Ocean (van Staal et al., 2011).
The most characteristic rocks of these terranes are Grenvillianage basement rocks (Western Sierras Pampeanas, Precordillera basement and Frontal Cordillera, San Rafael and Las Matras blocks) and a unique Early Paleozoic sedimentary cover (Precordillera).

Sato et al. (2000) proposed the existence of an N-S trending belt of Grenvillian-age rocks along the Western Sierras Pampeanas to the Las Matras block and interpreted this structure as the basement of the Cuyania Terrane (Fig. 1). The geological history of this belt is heterogeneous along its strike (see synthesis in Rapela et al., 2010, Varela et al., 2011).

The northern part of the Grenvillian belt is widely exposed at the Toro Negro, Umango, Maz and Espinal Ranges and in the surrounding lands. Following pioneering lithological descriptions by Hausen (1921), De Alba (1954), Turner (1964) and Furque (1972) and detailed works by Kilmurray and Iñiguez Rodriguez (1968), Kilmurray (1969, 1970, 1971) and Kilmurray and Dalla Salda (1971), the basement units of the Umango, Maz and Espinal Ranges, as well as the surrounding areas, were interpreted recently using isotopic constraints and provenance analyses (e.g., Casquet et al., 2006; Porcher et al., 2004; Varela et al., 2011). Portions of the Maz and Espinal Ranges revealed a different geodynamic history in the Early to Middle Proterozoic era, showing isotopic affinities with the Mesoproterozoic Arequipa-Antofalla Craton that are compatible with an autochthonous or para-autochthonous proto-Gondwanan origin (Casquet et al., 2006, 2008; Ramos, 2008). However, the Mesoproterozoic rocks of the Sierra de Umango (Juchi Orthogneiss - Varela et al., 1996, 2003a, 2008) and its supracrustal units are more comparable with the Sierra de Pie de Palo basement, indicating a Laurentian origin in this segment, as part of the Cuyania Terrane (Vujovich and Kay, 1998; Vujovich et al., 2004; Porcher et al., 2004; Varela et al., 2008, 2011).

Overlying the Grenvillian basement, the Early Paleozoic sedimentary strata of the Precordillera are the key to understanding the evolution of the Central Andes. Its palaeontological content, stratigraphy and structural evolution are supporting a Laurentian origin of the Cuyania Terrane (Keller, 1999; Benedetto, 2004; Thomas and Astini, 2003 and references therein). The Precordillera corresponds to a high-level $\mathrm{N}-\mathrm{S}$ trending fold-and-thrust belt formed during the Andean (Late Tertiary) Orogeny (Jordan et al., 1993) and purportedly related to shallow, eastward subduction of the Nazca Plate beneath the South America (Jordan et al., 1983). The Andean tectonics led to eastward thrusting above a buried basal décollement of the Cambrian to Late Tertiary sedimentary sequence (Baldis et al., 1984) and produced an overall crustal shortening by more than 50\% (Allmendinger et al., 1990; von Gosen, 1992; Jordan et al., 1993). The Andean shortening was preceded by Early Paleozoic (Ordovician to Devonian) deformation, linked by dominant $\mathrm{W}$-vergent folding and associated thrust faulting and a low-grade metamorphic overprint (up to greeschist facies), Carboniferous to post-Triassic normal faulting and Tertiary thin-skinned tectonic activity, that highlight the polyphase structural evolution of the Precordillera (von Gosen, 1992, 1995, 1997; von Gosen et al., 1995; Thomas and Astini, 2007).

South of the basement rocks of the Sierra de Umango, the Precordillera sedimentary rocks are represented by the Cerro Totora Formation, an Early Cambrian syn-rift deposit comprising a succession of red beds and dolomites interlayered with evaporite (Thomas and Astini, 2003); the San Juan Formation, which is mostly composed of Ordovician shallow-marine carbonates that form the top of a passivemargin sequence (Thomas and Astini, 2003) and the Trapiche Group, which consists of Late Ordovician siliciclastic deposits in a synorogenic clastic wedge (Thomas and Astini, 2003). Devonian siliciclastic sedimentary rocks composed of sandstones, pelites, conglomerates and diamictites (Fauqué et al., 2004) in the Punilla Formation form the western boundary of the Umango basement rocks. 
An extensive retroarc basin in this area, associated to the magmatic arc from the Gondwanic Tectonic Cycle (Pankhurst and Rapela, 1998), is characterised by the Paganzo Group, which was active during the Carboniferous to Permian periods (Limarino et al., 2002 and references therein). These sedimentary rocks are overlain unconformably above the Precordillera and the basement rocks. Mesozoic deposits (Triassic and Cretaceous rocks) are associated with extensional events on the Gondwana margin and the early rifting of the Atlantic Ocean (Ramos, 1988a).

Cenozoic deposits are mainly related to the Andean foreland basins. These rocks, mainly the Puesto La Flecha, Vinchina, Zapallar, El Corral and Toro Negro formations from the Oligocene to Miocene epochs, are frequently deformed (Caminos and Fauqué, 1999).

\section{Geology of the Sierra de Umango}

The crystalline rocks of the Sierra de Umango are composed of a Mesoproterozoic basement unit, called Juchi Orthogneiss; two supracrustal sequences of Ordovician-age metamorphism (Varela et al., 2011) and poorly constrained sedimentary age, named the Tambillo and Tambillito units; the El Cordobés metamafic sequence; the Ordovician pre- to syn-collisional El Peñon Granite (Varela et al., 2011) and the late- to post-collisional Guandacolinos and Cerro Veladero Granites. The La Troya Marble, Punilla Formation, Late Paleozoic sedimentary rocks, and Mesozoic and Cenozoic layers complete the geological units exposed at the Sierra de Umango (Fig. 3).

\subsection{Juchi orthogneiss}

The basement unit of the Sierra de Umango consists mainly of hornblende-biotite tonalitic gneisses, biotite granodioritic gneisses and migmatites. The migmatites are characterised by fine-grained trondhjemitic leucosome, biotite and hornblende-rich melanosome and paleosome with $20 \%$ mafic mineral content. Metabasic rocks are intercalated within the gneissic sequence in centimetresto decimetres-thick bands that locally contain garnet and clinopyroxene. Boudins and metres-thick bands of retroeclogites/highpressure mafic granulites were described in the northwestern area of the Sierra de Umango in the Agua La Falda region (González et al., 2005). Red-pinkish leucocratic decimetres- to metres-thick bands of biotite syenogranitic gneisses are common, often with mylonitic foliation. Syenogranitic veins have intruded into the gneissic package and are deformed with it.

The Juchi Orthogneiss occurs in synformal structures and overlies the Tambillo Unit, limited by ductile thrust faults. These structures have been interpreted as klippen (see description below), called Juchi Klippe and La Falda Klippe (Figs. 3, 4 and 8). Gneissic banding is the main structure in these rocks and represents the S2 foliation. Relics of S1 foliation have been preserved in D2 intrafolial folds and S2 often exhibits mylonitic and protomylonitic fabrics. Open-to-tight folds deform the S2 surface, essentially in the limbs of the synformal structure (Fig. 8). These folds could be related to the D3 or D4 folding phases (see synthesis of the tectonometamorphic events in Table 1 and further reading below).

The mineralogical assemblages of the felsic gneisses generally comprises biotite, quartz, plagioclase, K-feldspar, hornblende, garnet, opaque minerals and occasionally clinopyroxene and epidote group minerals; the metamafic rocks contain garnet, clinopyroxene, quartz, plagioclase, hornblende, rutile, titanite and opaque minerals. These mineral assemblages suggest that these rocks were metamorphosed under medium- to high-pressure upper amphibolite-to-granulite facies conditions.

The ages of Juchi Orthogneiss range from $1216 \pm 29$ Ma (Varela et al., 2003b) to $1084 \pm 7$ Ma (Varela et al., 2008) and have been interpreted as dating the time of crystallisation. New SHRIMP U/Pb zircon data indicate inherited Mesoproterozoic cores (in the same interval cited above) and Ordovician rims ( $474 \pm 12$ Ma; Varela et al., 2011), suggesting a metamorphic overprint associated with the Famatinian collisional event (Varela et al., 2011).

A detailed metamorphic study of this unit is required to better understand the tectono-metamorphic evolution of these rocks, especially with respect to their pre-Ordovician history.

\subsection{Tambillo Unit}

The Tambillo Unit is exposed in a major part of the Sierra de Umango including a thick shear zone along its western boundary (PFSZ) and displays important differences between the western and the eastern portions (Fig. 3).

In the western portion, marble beds occur in ten- to hundredmetre-thick layers interlayered within amphibolites, calcsilicate rocks and feldspatic schists (meta-greywackes). The eastern area is characterised by intercalations of biotite-muscovite schists, biotite-muscovite-quartz schists, quartzites, calcsilicate rocks, amphibolites and minor marbles.

The main structure is characterised by an S2 transposition foliation which is generally parallel to the compositional layering ( $\mathrm{S} 0$ ) and is defined by mica-rich bands in micaceous schists, discontinuous kyanite-sillimanite and biotite-rich bands interleaved with granoblastic quartz and plagioclase-rich sub-millimetre-thick bands in feldspatic schists and alternating hornblende-rich/plagioclase-rich bands in amphibolites. D2 recumbent folds with relics of S1 foliation preserved in their hinges are also characteristic. These structures are well developed where the amphibolites are interlayered with marbles. D3 and D4 folds are defined by close-to-open asymmetric folds that deform the S2 foliation. E-W open folds outline the D5 deformational phase, often with a high-angle plunging axis.

A well-developed shear zone affects the Tambillo Unit along its western boundary. The NNE trending La Puntilla-La Falda Shear Zone (PFSZ) is approximately $4 \mathrm{~km}$ in width and more than $38 \mathrm{~km}$ in length. Alternating aluminous silicate-garnet-plagioclase-quartz-biotite mylonites, marble breccias and amphibolite boudins are the major lithologies, but minor porphyroclastic, grey mylonitic granites and dark-grey ultramylonites also occur. A tabular body of garnet-bearing metagabbro is exposed at Cerro Cacho (4000 m above sea level) (Figs. 3 and 4). The protomylonitic to mylonitic foliation is correlated to the main regional S2 foliation, which is typified by fine-grained biotite-rich bands, quartz ribbons and feldspar and garnet porphyroclasts. The mylonitic foliation was modified by upright, open D4 folds.

The mineralogical assemblages show that these rocks have undergone a metamorphism of upper amphibolite facies. According to our data, the metamorphic grade varies from muscovitebearing rocks in the eastern portion to conditions beyond the muscovite-breakdown reaction, which produces K-feldspar in the presence of sillimanite and/or kyanite in the western region and the PFSZ (Meira, 2010).

Isotopic $\mathrm{Sr}-\mathrm{C}-\mathrm{O}$ studies on marbles of the Tambillo Unit suggest a Neoproterozoic (580-640 Ma) depositional age for the siliciclastic-carbonate sequence (Varela et al., 2001). This age is tentative because of the assumption that the rocks remained close system with respect to these isotopic systems during the mediumto high-grade metamorphism and that such rocks have preserved their original sedimentary isotopic compositions.

\subsection{Tambillito Unit}

The Tambillito Unit consists mainly of alternating staurolite and/or garnet-bearing mica schists, quartzites, minor amphibole 


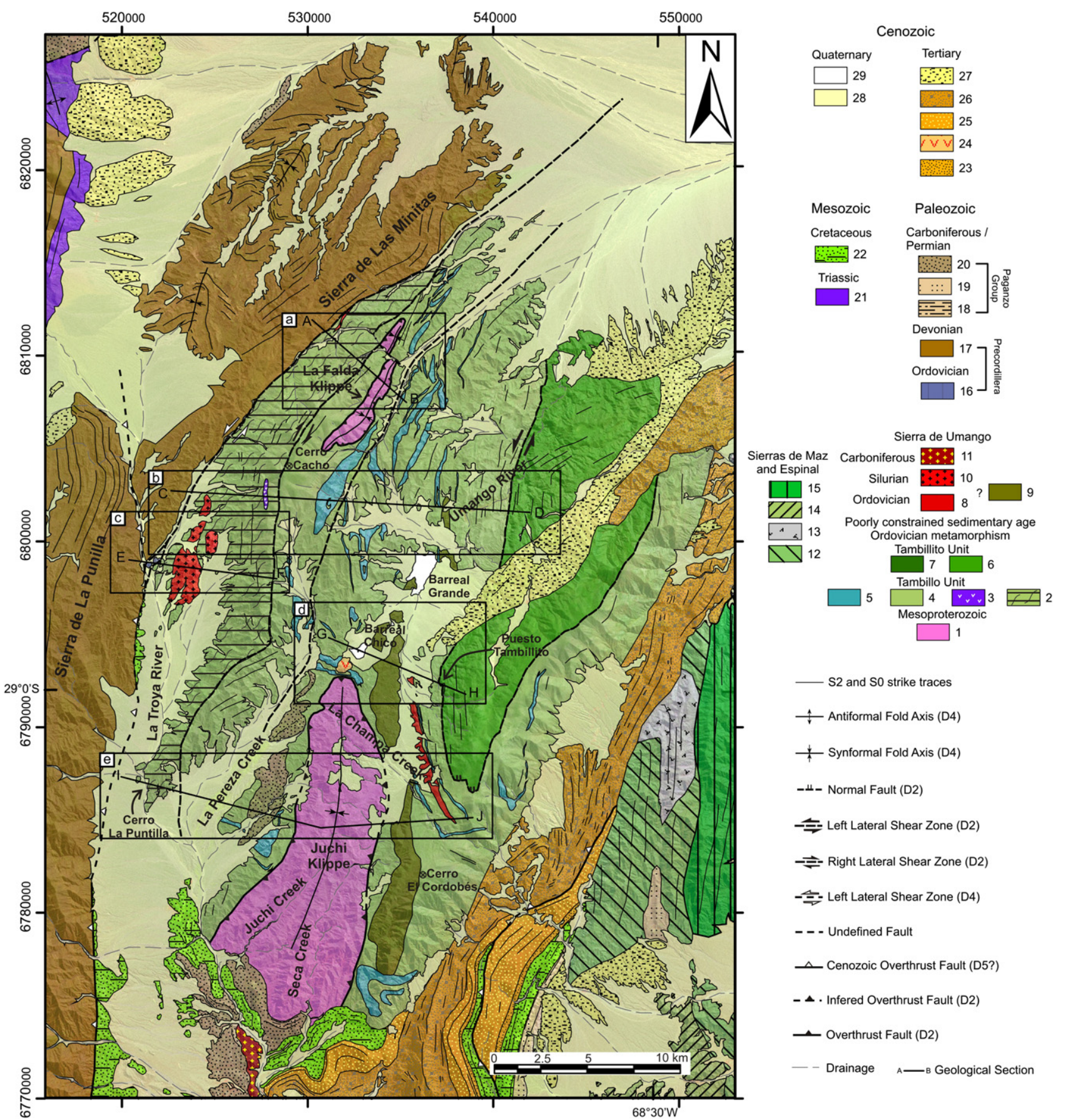

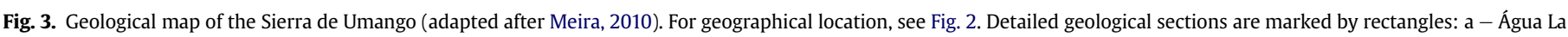

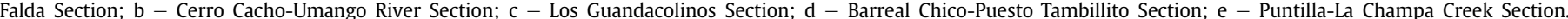

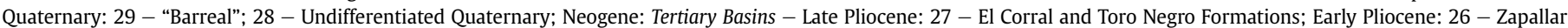

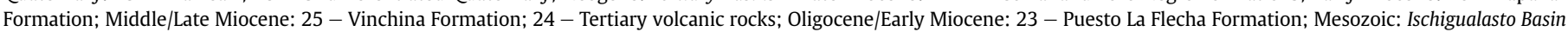

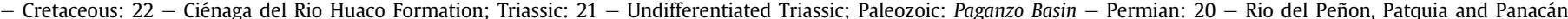

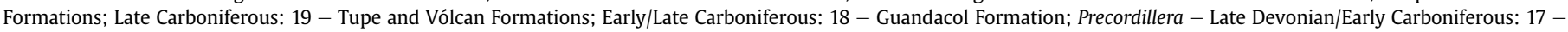

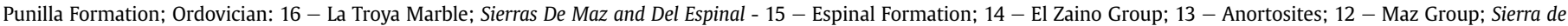

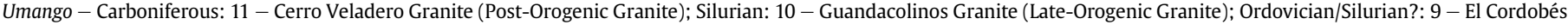

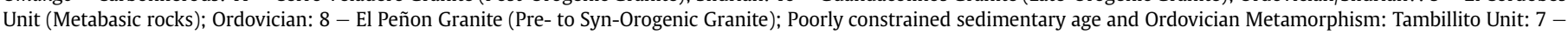

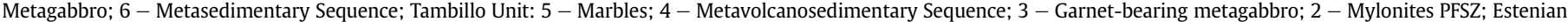
Mesoproterozoic: 1 - Juchi Orthogneiss. A color version of this figure is available in the online edition.

schists, amphibolites and calcsilicate rocks. A tabular to lenticular body of coarse-grained metagabbro is exposed in the contact between the Tambillo and Tambillito units (Figs. 3 and 6).
All the information about this unit comes from the area east of the Puesto Tambillito and the easternmost Umango River section. The southern and eastern limits were delineated with satellite images and need to be verified in the future. 

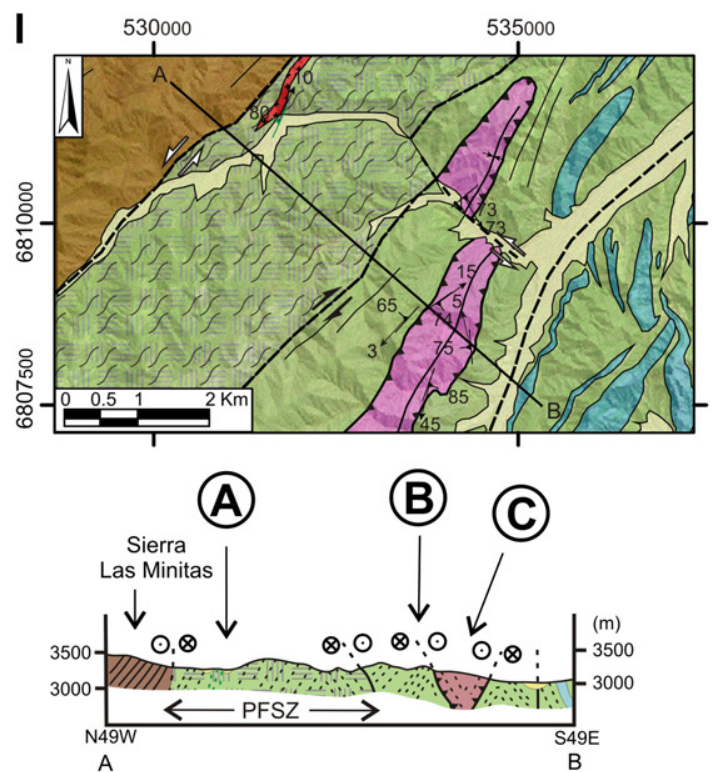

$Y^{35} \begin{aligned} & \text { Main foliation (S2) } \\ & \text { (strike and dip angle) }\end{aligned}$

35 Foliation (S4) (strike and dip angle)

${ }^{35}$ Stretching and mineral lineations (plunge angle)

_ $\mathrm{S} 2$ and S0 strike traces

$\therefore$ Protomylonitic foliation (S4)

$\therefore$ Main foliation (S2)

/ Bedding (SO) $\downarrow$ Synformal fold axis (D4)

Left lateral shear zone (D2)

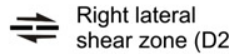

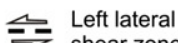

$\approx$ shear zone (D4)

_ - Undefined fault

ـ Overthrust fault (D2)

A-B Geological section

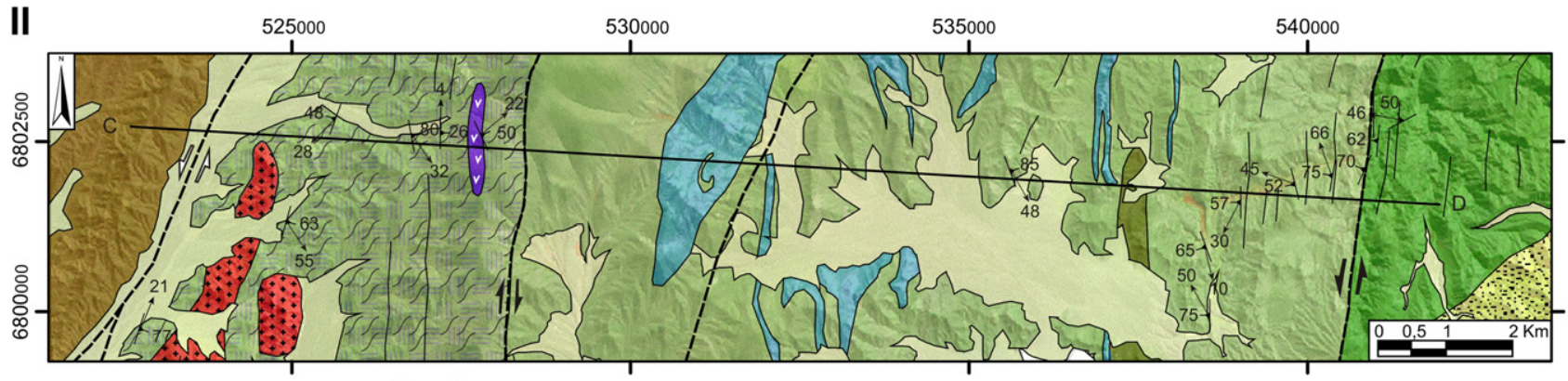

(A)B

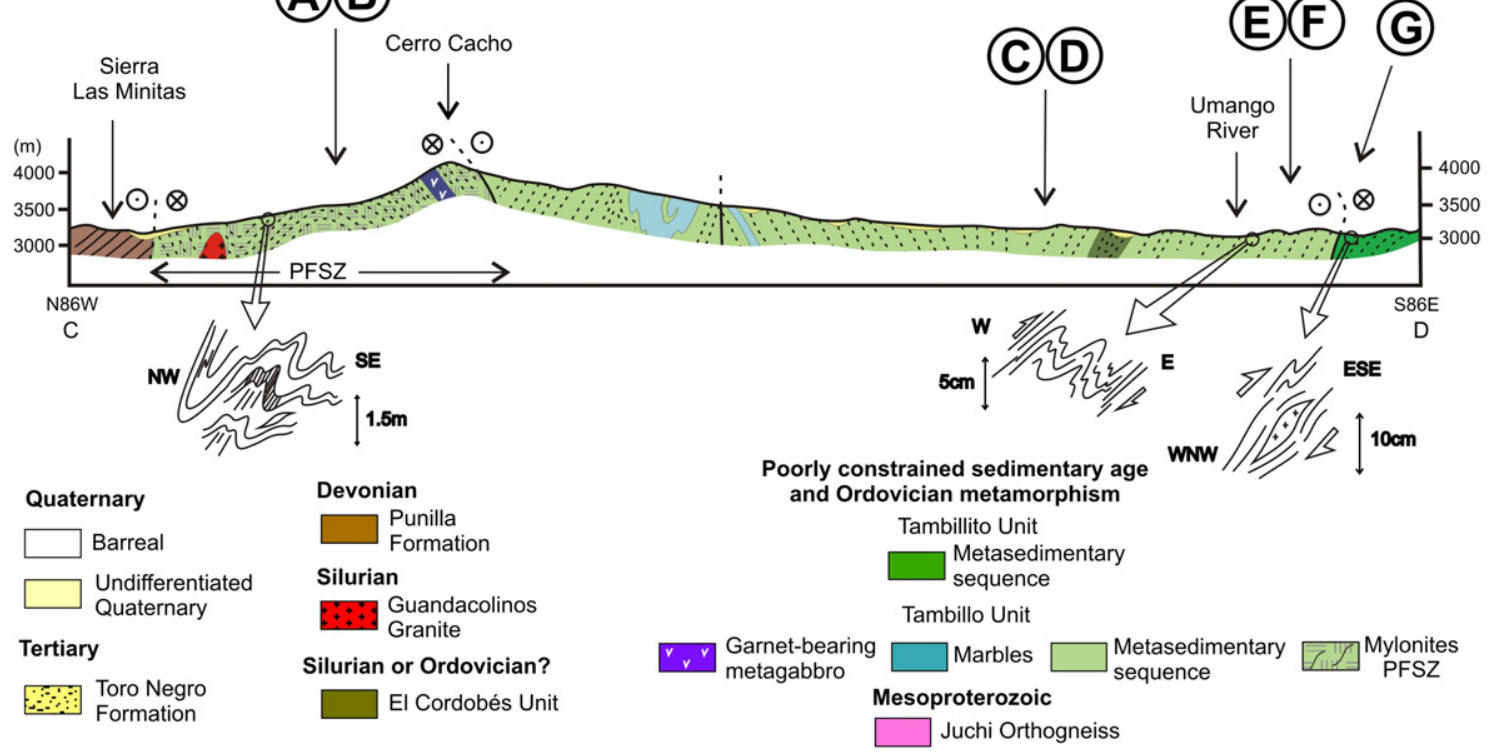

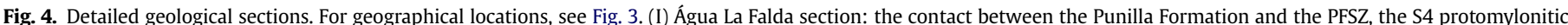

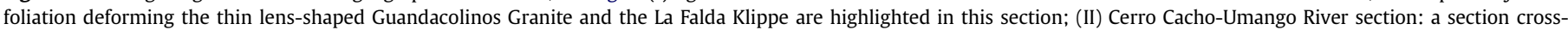

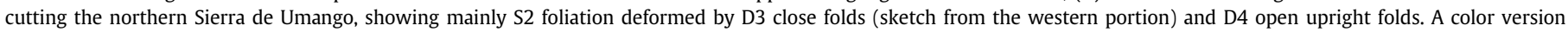
of this figure is available in the online edition.

The observed contact between the Tambillo and Tambillito units is tectonic, characterized by abrupt change in the metamorphic grade of the metasedimentary rocks, and it is defined by a folded steeply dipping fault. The rocks of the Tambillo Unit indicate metamorphic conditions up to upper amphibolite facies, reaching partial melting reactions, while the metapelitic rocks of Tambillito Unit show metamorphism with stability of garnet and staurolite in the lower amphibolite facies conditions. The small amount of 

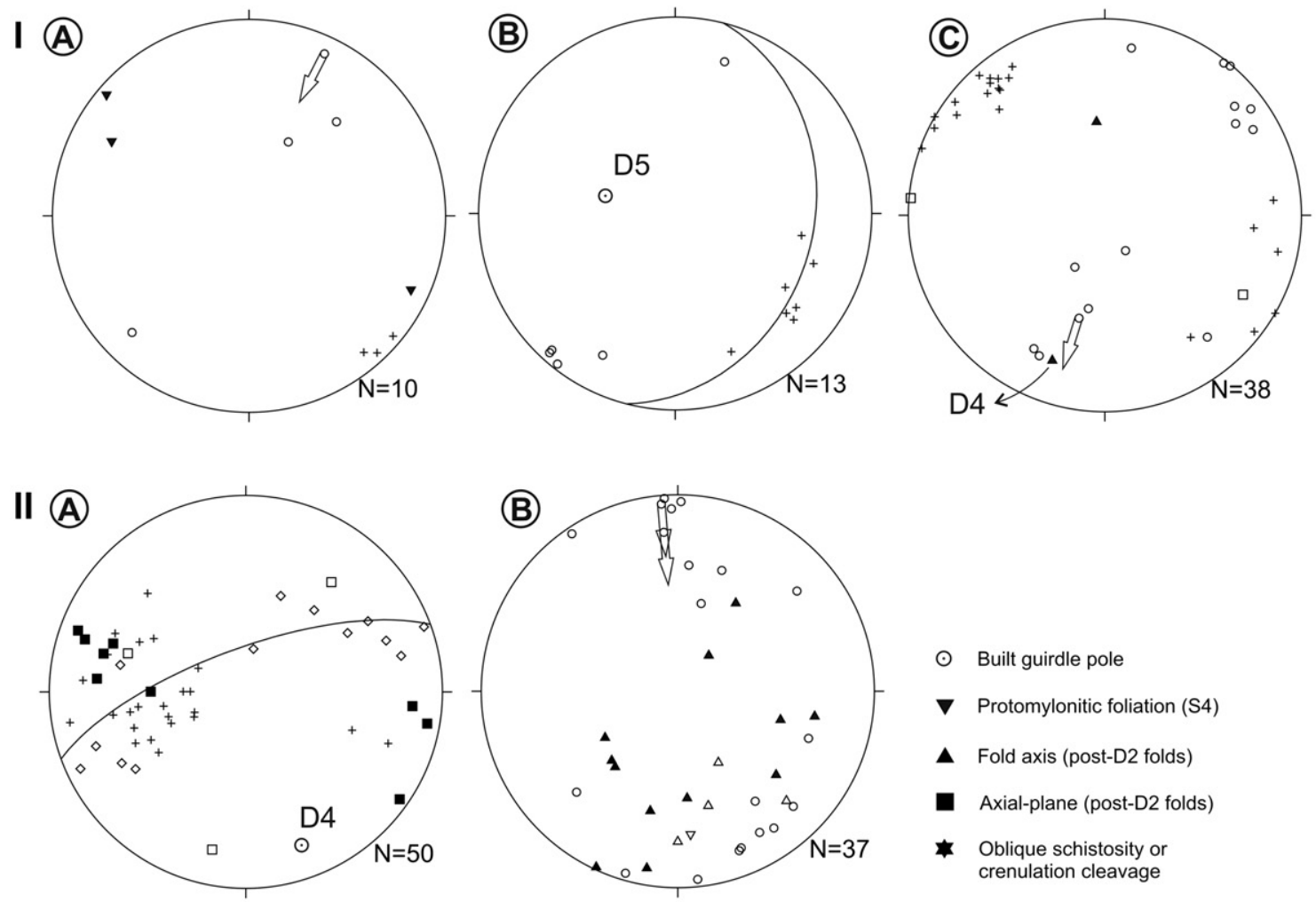

$\odot$ Built guirdle pole

$\boldsymbol{\nabla}$ Protomylonitic foliation (S4)

A Fold axis (post-D2 folds)

Axial-plane (post-D2 folds)

* Oblique schistosity or crenulation cleavage

$\nabla \quad$ Mullion lineation (L2)
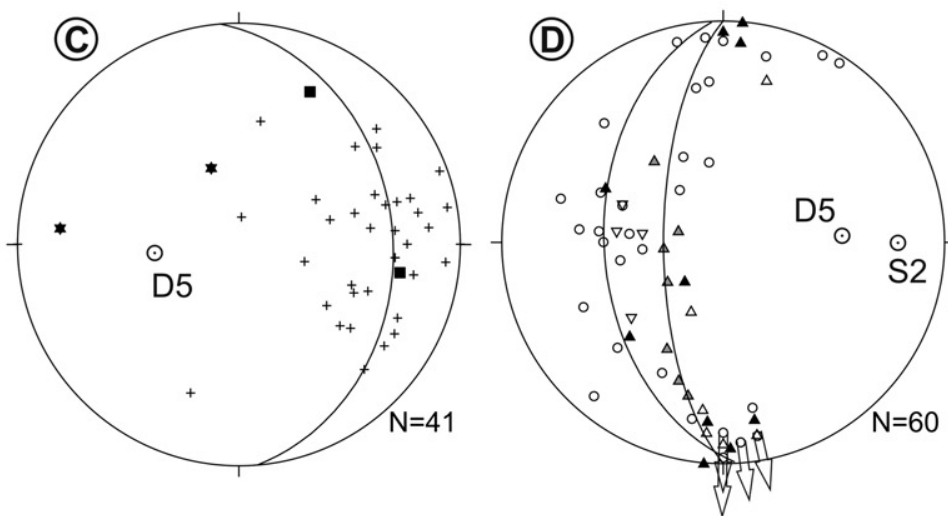

$\triangle$ Fold axis (D2 folds)

$\triangle$ Hinge line (D2 sheath folds)

$\square \quad$ Axial-plane (D2 folds)

Kinematic sense direction

O Mineral and stretching lineations (L2)

$\diamond \quad$ Main foliation S2 (metagabbro)

$+\quad$ Main foliation S2
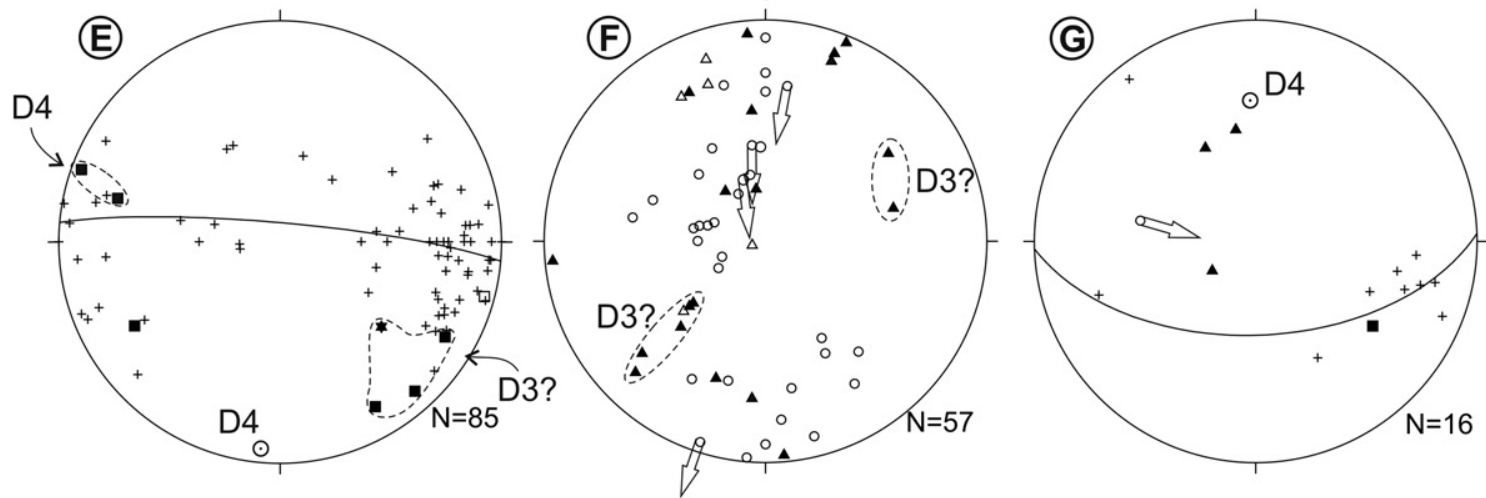

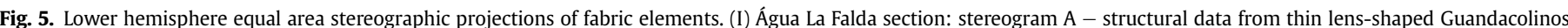

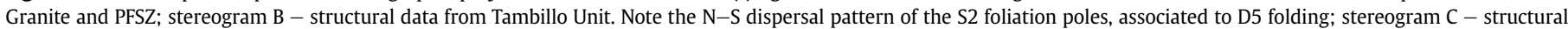

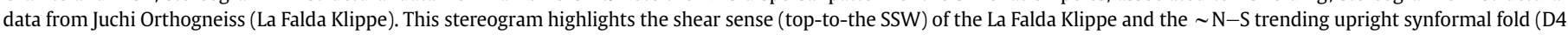

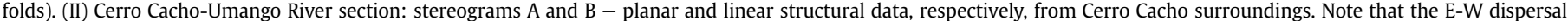

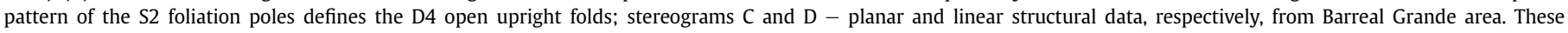

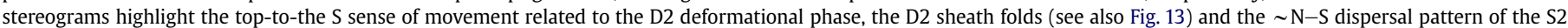

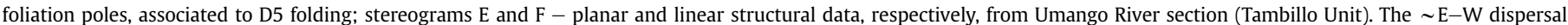

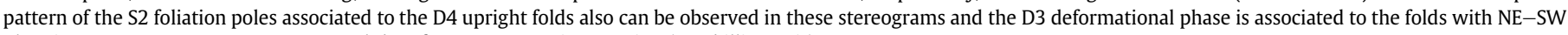
plunging axes; stereogram G - structural data from Umango River section (Tambillito Unit). 

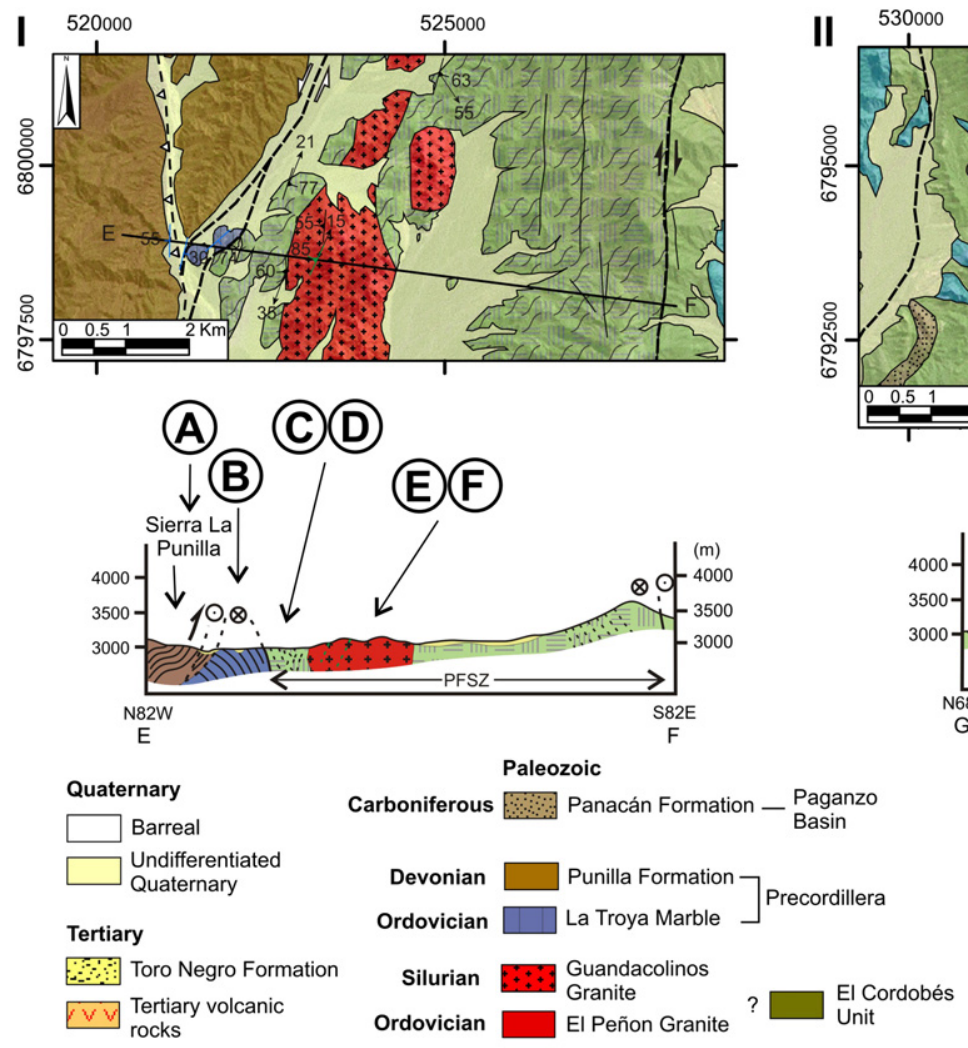

35 Main foliation (S2)

(strike and dip angle)

35 Foliation (S4)

(strike and dip angle)

35 Stretching and mineral

lineations (plunge angle)

$\mathrm{S} 2$ and $\mathrm{S} 0$ strike traces

$\therefore$ Protomylonitic foliation (S4)

$\therefore$ Main foliation (S2)

Bedding (SO)
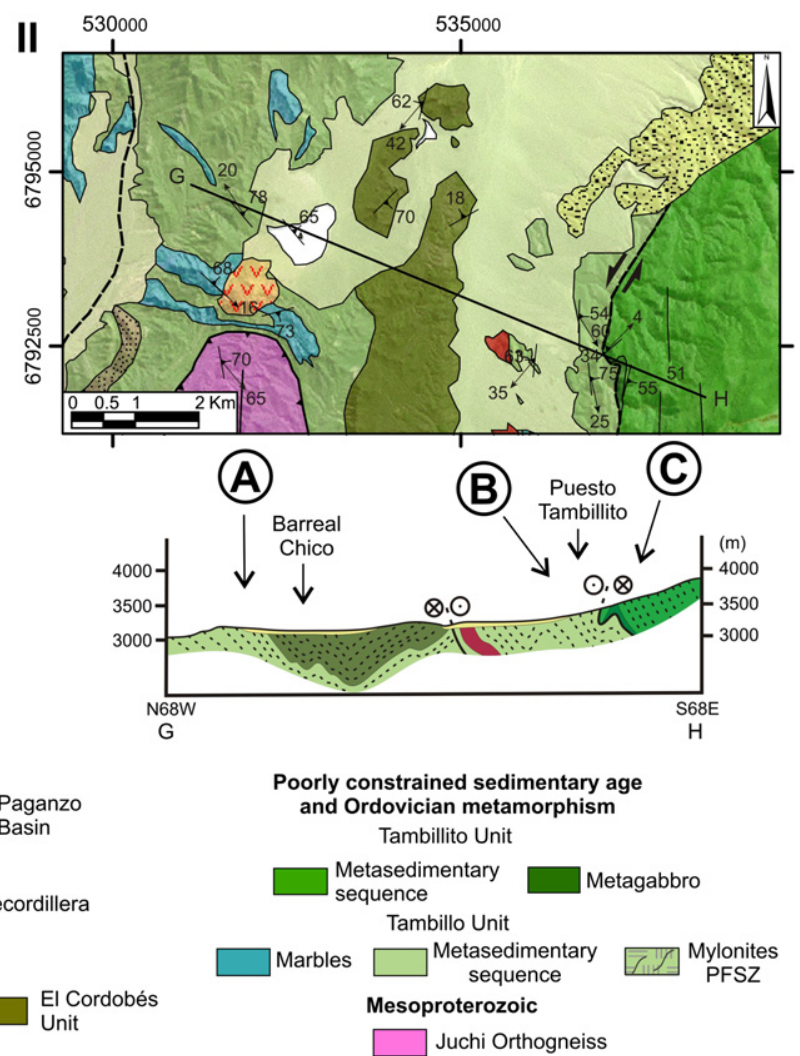

$\downarrow$ Synformal fold axis (D4)

$\underline{=}$ Left lateral shear zone (D2)

- - Undefined fault

ـ Overthrust fault (D2)

- $\Delta \quad$ Cenozoic overthrust fault

A-B Geological section

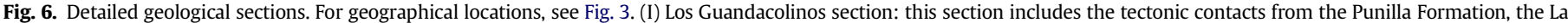

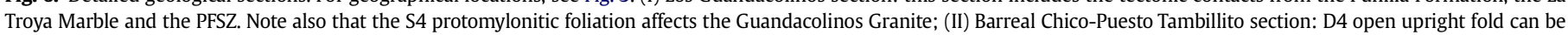

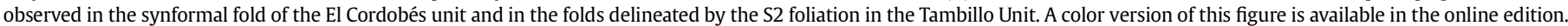

structural data and the geological interpretation based on satellite images suggest that the Tambillito Unit lies structurally over the Tambillo Unit in an upright-to-E-vergent synformal fold (interpreted as D4 fold, on basis of its geometry and orientation). Based on a limited number of kinematic indicators, the western boundary represents a sinistral shear zone folded in an overturned limb of a synformal fold with a half-wavelength of approximately $5 \mathrm{~km}$. An interpreted normal sense direction at the hinge (southern limit) suggests movement of this metasedimentary unit in the E to NNE direction.

The main schistosity is interpreted as an S2 surface, defined mostly by mica-rich bands and biotite and sillimanite-rich bands interlayered within lenticular quartz-rich bands. In mafic rocks, S2 is characterised by alternating mafic and felsic bands formed by hornblende/epidote group minerals and quartz/plagioclase.

The metapelitic rocks record medium-grade metamorphism (intermediate pressure/amphibolite facies), varying from the staurolite zone in Puesto Tambillito to the sillimanite zone (sillimanite first isograde) in the eastern Umango River section. Mafic rocks show a mineral assemblage, composed of hornblende and epidote minerals indicative of medium to lower amphibolite facies. These estimated metamorphic conditions suggest a lower metamorphic grade than those found in the underlying Tambillo Unit (Meira, 2010).

TIMS U/Pb zircon dating from an amphibolite of the Tambillito Unit yielded an upper intercept of $1108 \pm 4$ Ma and a lower intercept of $428 \pm 12 \mathrm{Ma}$ (Varela et al., 2008, 2011). The authors interpret the Mesoproterozoic age as representing the crystallisation timing of the mafic igneous protolith (as dykes or sills), while the Silurian age could correspond to a later thermal event associated with the Famatinian collisional event. Varela et al. (2008) did not discard the possibility of the dated zircon grains are xenocrysts collected from the host rocks.

\subsection{El Cordobés Unit}

The predominance of metabasic rocks in the Cerro El Cordobés was first documented by Hausen (1921). This unit corresponds to an N-S and NNE-SSW trending belt (Fig. 3) composed mostly of coarse-grained hornblende-bearing metagabbros, amphibolites and (garnet)-(biotite)-epidote-hornblende gneisses.

Near Barreal Grande and the surroundings of Barreal Chico (Fig. 3), coarse-grained hornblende-bearing metagabbros, minor amphibolite and mica-quartz schist are exposed. At La Champa Creek occurs 

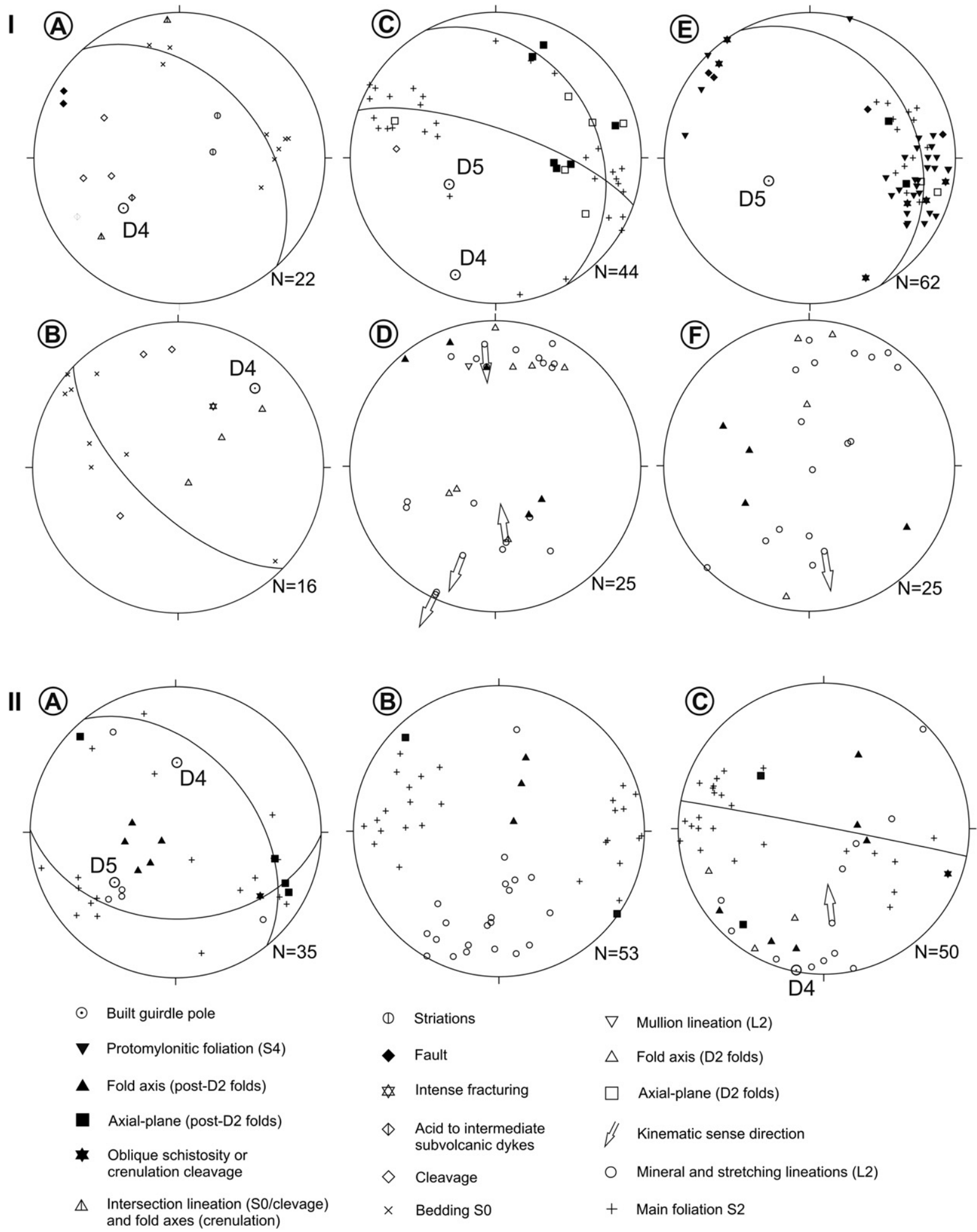
(1) Striations
$\nabla \quad$ Mullion lineation (L2)
- Fault
$\triangle$ Fold axis (D2 folds)
Intense fracturing
$\square \quad$ Axial-plane (D2 folds)
$\bowtie \quad$ Acid to intermediate
Kinematic sense direction
$\diamond \quad$ Cleavage
Mineral and stretching lineations (L2)
$\times \quad$ Bedding S0
$+\quad$ Main foliation S2

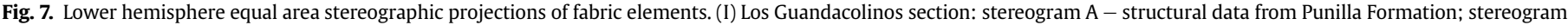

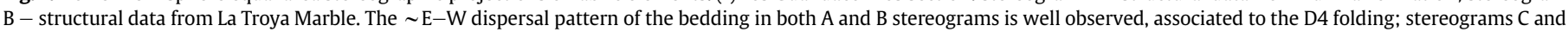

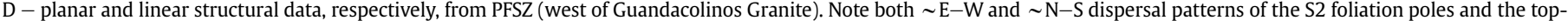

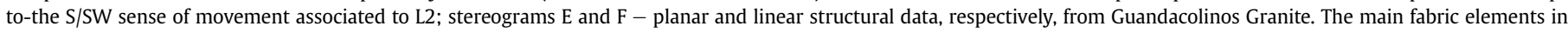

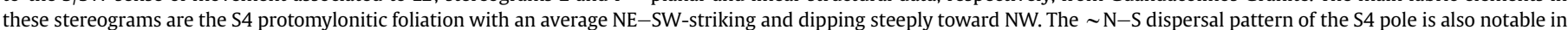

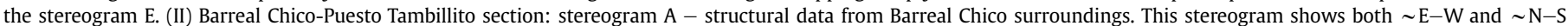

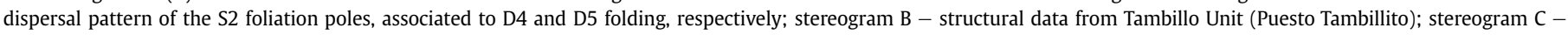

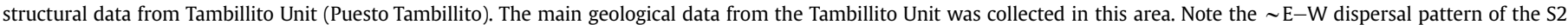
foliation poles and the top-to-the $\mathrm{N}$ sense of movement associated to $\mathrm{L} 2$. 

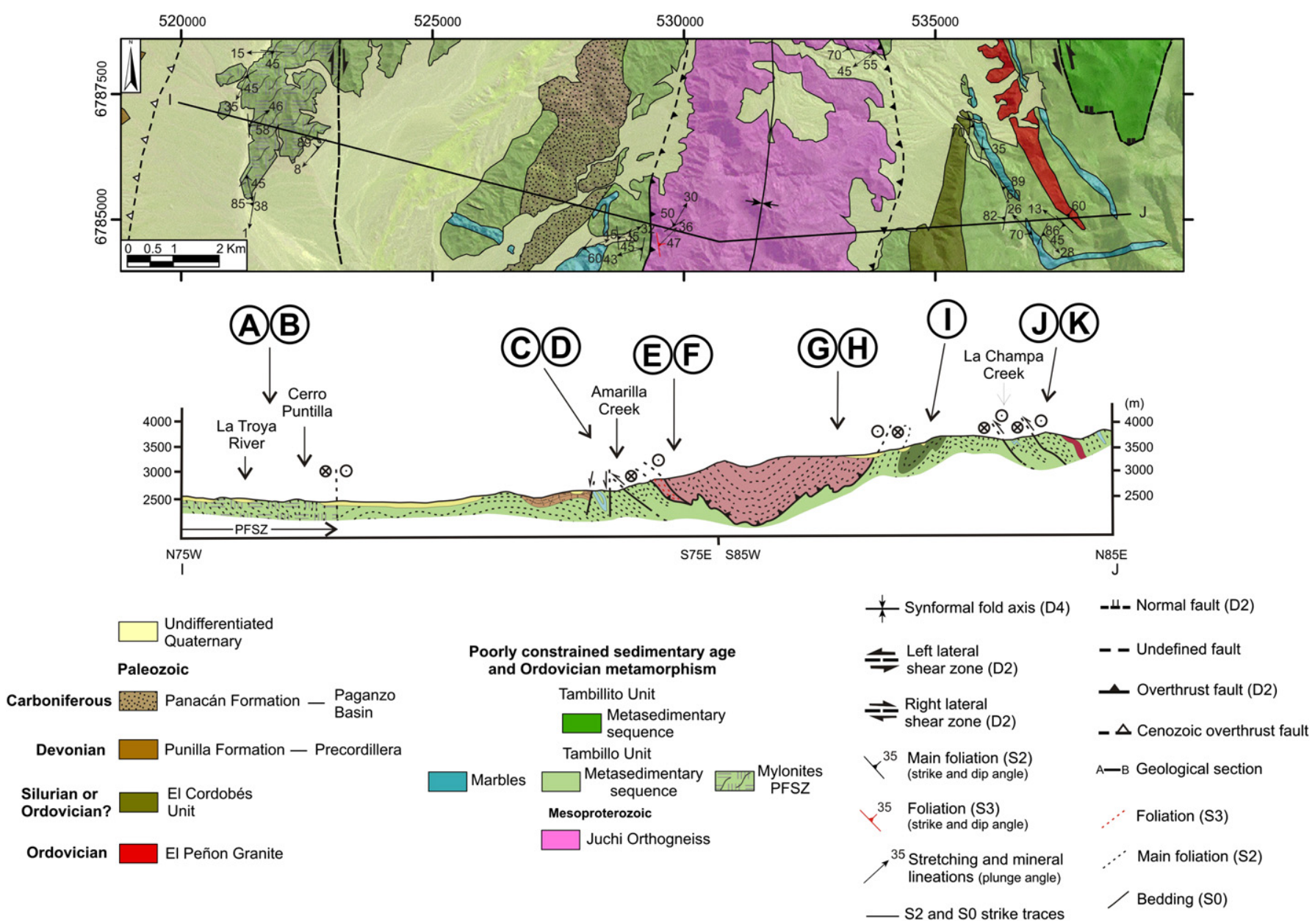

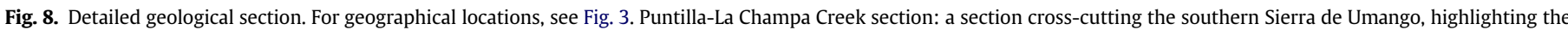
D4 synformal fold of the Juchi Klippe, W- to SW-vergent D3 folds and associated thrust to oblique faults. A color version of this figure is available in the online edition.

a sequence of mafic hornblende-bearing gneisses. The main foliation is concordant with the S2 foliation of the country rocks.

Structurally, the El Cordobés Unit lies above the Tambillo Unit in an interpreted, but not well defined, synformal structure.

A characteristic feature of the coarse-grained hornblendebearing metagabbro is the presence of plagioclase-corona around opaque minerals that commonly define a stretching lineation.

Varela et al. $(2008,2011)$ presented a TIMS U/Pb zircon age from a metagabbro of $446 \pm 3 \mathrm{Ma}$ and interpreted this data as the magmatic crystallisation age of the El Cordobés Unit. Alternatively, this data could represent a metamorphic overprint age of an older (Mesoproterozoic?) mafic magmatism (Varela et al., 2011).

\subsection{El Peñon Granite}

A tabular, lens-shaped body of mylonitic granitoids is exposed in the southeastern area of the Sierra de Umango (Fig. 3). This body of granitoids corresponds to an NNW-SSE trending structure, $8.5 \mathrm{~km}$ long and $400 \mathrm{~m}$ wide, interlayered tectonically with the rocks of the Tambillo Unit and near the contact zone with Tambillito Unit (Figs. 3, 6 and 8). In this area, there are predominantly reddish mylonitic biotite granites, intensively foliated and lineated, intercalated with greyish mylonitic hornblende-biotite-bearing granodiorites, usually porphyroclastic and lineated. Deformed veins frequently occur in the Tambillo Unit, mainly in its eastern portion. Pegmatitic dykes occur discordantly and concordantly to the main foliation and are more abundant along the Umango River section. At the margin of the
Umango River, a small body of equigranular leucocratic coarsegrained biotite granite is exposed, with an exposure area with a diameter of approximately ten metres. These intrusive rocks are thought to correlate with the El Peñon Granite.

This rock has been interpreted as a syn-orogenic granite (TIMS $\mathrm{U} / \mathrm{Pb}$ zircon ages of $487 \pm 1 \mathrm{Ma}$ - Varela et al., 2011) associated with the Ordovician collisional event (Varela et al., 2000, 2008, 2011).

\subsection{Guandacolinos and Cerro Veladero Granites}

Two granitic stocks were differentiated in the Sierra de Umango: Guandacolinos Granite (Varela et al., 1996) and Cerro Veladero Granite (Cingolani et al., 1993). In this study, the Guandacolinos Granite was studied in the field, and the lithological contacts of both stocks were interpreted based on satellite images (Fig. 3).

The Guandacolinos Granite is predominantly composed of porphyritic and hypidiomorphic pinkish to greyish medium- to coarse-grained biotite syenogranite, exposed along the western PFSZ (Fig. 6). This granite varies from hololeucocratic to leucocratic rocks, and local sub-parallel alignment of euhedral elongate feldspar crystals occurs, which suggests magmatic or submagmatic flow structures (according to Paterson et al., 1989). Mafic microgranular enclaves and xenoliths from country rocks are common. Discrete bands with protomylonitic foliations are well developed in some localities, indicating that a post-magmatic solid-state deformation affected these granitic rocks (following the assumptions of Paterson et al., 1989). 

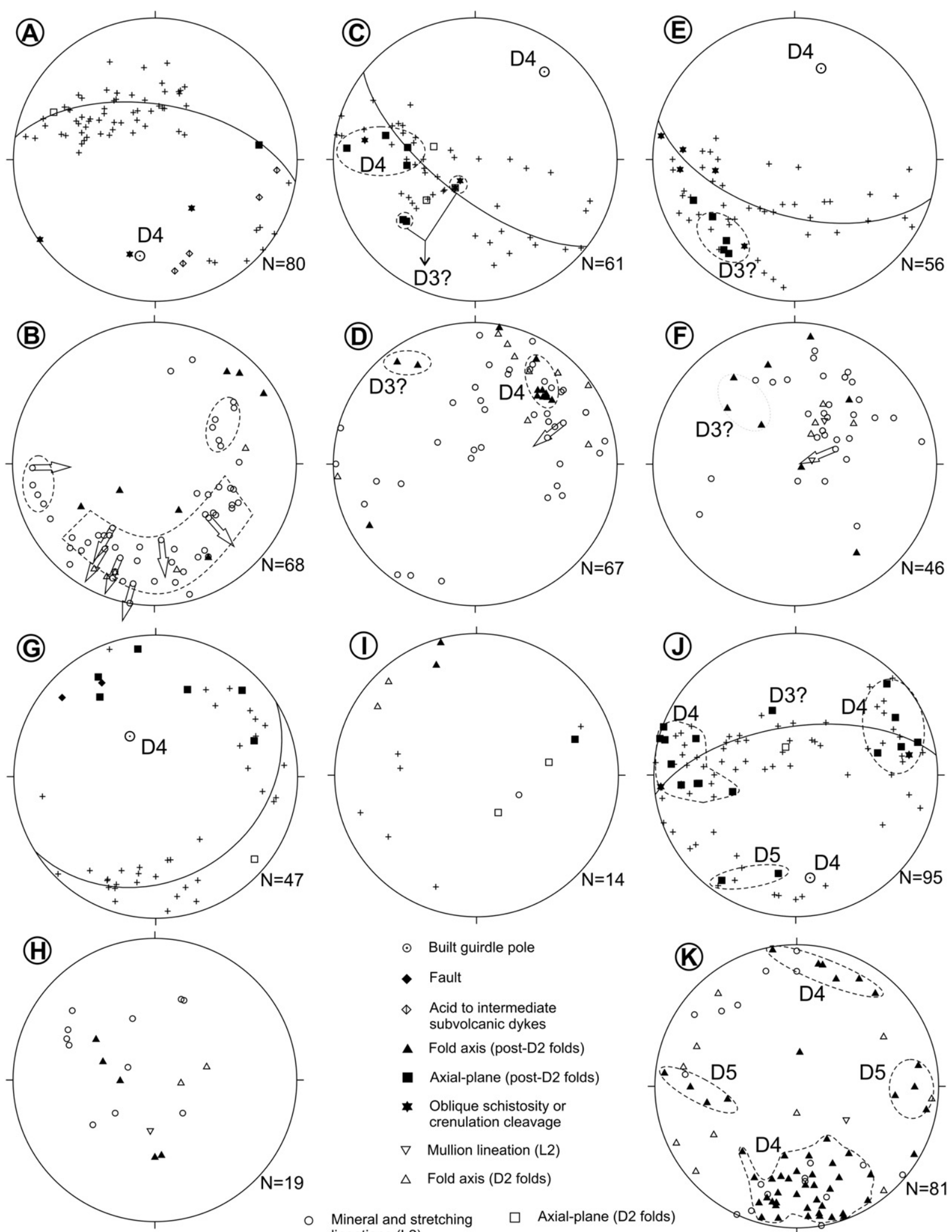
$\odot$ Built guirdle pole
- Fault
$\diamond \quad$ Acid to intermediate subvolcanic dykes
- Fold axis (post-D2 folds)
- Axial-plane (post-D2 folds)
* Oblique schistosity or crenulation cleavage
$\nabla$ Mullion lineation (L2)
$\Delta \quad$ Fold axis (D2 folds) Mineral and stretching
lineations (L2)
$\square \quad$ Axial-plane (D2 folds)
" Kinematic sense direction
+ Main foliation S2

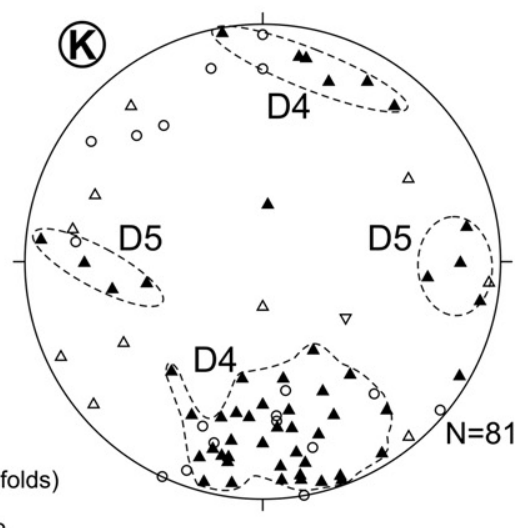

Fig. 9. Lower hemisphere equal area stereographic projections of fabric elements. Puntilla-La Champa Creek section: stereograms A and B - planar and linear structural data, respectively, from PFSZ (Cerro Puntilla). These stereograms show the $\sim \mathrm{E}-\mathrm{W}$ dispersal pattern of the S2 foliation poles, associated to the D4 folding and the major top-to-the S sense of movement associated to the L2. A group of NE-SW plunging L2 lineation shows top-to-the E sense of movement and could be associated to synchronously detachment shear zones; stereograms C and D - planar and linear structural data, respectively, from Tambillo Unit (Amarilla Creek). The D4 folding phase is shown in these stereograms with built guirdle pole concordant with the NE plunging fold axes. The D3 folds are tentatively correlated to the NW plunging fold axes; stereograms E and F - planar and linear structural data, respectively, from Juchi Orthogneiss (Amarilla Creek). The $\sim \mathrm{E}-\mathrm{W}$ dispersal pattern of the S2 foliation poles is the major element in these stereograms. The D3 folding phase is associated to NW plunging fold axes and gently dipping axial planes toward NE; stereograms $\mathrm{G}$ and $\mathrm{H}$ - planar and linear structural data, respectively, from Juchi Orthogneiss (La Champa Creek). The D4 folding dispersal pattern is also notable in these stereograms; stereogram I - structural data from El Cordobés Unit (La Champa Creek); stereograms J and K - planar and linear structural data, respectively, from Tambillo Unit (La Champa Creek). These stereograms highlight both D4 and D5 folding, featuring mainly the D4 dispersal pattern. 
Table 1

Sequence of tectonic events, deformational phases, structures, metamorphism and magmatism of the Sierra de Umango.

\begin{tabular}{|c|c|c|c|c|c|c|}
\hline $\begin{array}{l}\text { Tectonic } \\
\text { event }\end{array}$ & & $\begin{array}{l}\text { Deformational } \\
\text { phase }\end{array}$ & Structures & Metamorphism & Magmatism & Age \\
\hline \multirow[t]{5}{*}{$\begin{array}{r}\text { Famatinian } \\
\text { Orogeny }\end{array}$} & $\begin{array}{l}\text { Main orogenic } \\
\text { Phase }\end{array}$ & D1 & $\begin{array}{l}\text { Relics of S1 folded } \\
\text { by D2 folds and } \\
\text { internal foliation } \\
\text { within interkinematics } \\
\text { porphyroblasts of } \\
\text { staurolite and garnet }\end{array}$ & $\begin{array}{l}\text { Prograde metamorphism } \\
\text { from greenschist to } \\
\text { amphibolite facies }\end{array}$ & & \\
\hline & & D2 & $\begin{array}{l}\text { The main metamorphic } \\
\text { structure defined by } \\
\text { transposition or mylonitic } \\
\text { S2 foliation. D2 intrafolial } \\
\text { isoclinal tight folds, sheath } \\
\text { folds and fishhook rootless folds }\end{array}$ & $\begin{array}{l}\text { Peak P-T conditions from } \\
\text { lower amphibolite-to- } \\
\text { granulite facies }\end{array}$ & $\begin{array}{l}\text { El Peñon } \\
\text { Granite }\end{array}$ & $\begin{array}{l}\text { Ordovician } \\
(480-450 \mathrm{Ma})\end{array}$ \\
\hline & & D3 & $\begin{array}{l}\text { Close-to-tight asymmetric, } \\
\text { inclined-to-recumbent folds. } \\
\text { D3 folding is usually } \\
\text { associated to disrupted limbs } \\
\text { in thrust faults and axial plane } \\
\text { schistosity or oblique } \\
\text { schistosity (S3) }\end{array}$ & $\begin{array}{l}\text { Retrograde metamorphism } \\
\text { from lower amphibolite-to- } \\
\text { greenschist facies }\end{array}$ & $\begin{array}{l}\text { El Cordobés } \\
\text { Unit (?) }\end{array}$ & \\
\hline & $\begin{array}{l}\text { Late- to Post- } \\
\text { orogenic Phase - }\end{array}$ & & & & $\begin{array}{l}\text { Guandacolinos } \\
\text { Granite }\end{array}$ & Silurian (?) \\
\hline & Chanica Tectonics & D4 & $\begin{array}{l}\text { Open-to-close, upright-to- } \\
\text { east-vergent, N-S to NE-SW } \\
\text { trending D4 folds. Discrete shear } \\
\text { zones and S4 protomylonitic } \\
\text { foliation }\end{array}$ & Greenschist facies & & $\begin{array}{l}\text { Devonian-Early } \\
\text { Carboniferous } \\
(\sim 375-345 \mathrm{Ma})\end{array}$ \\
\hline $\begin{array}{r}\text { Gondwanic } \\
\text { Orogeny }\end{array}$ & & & & & $\begin{array}{l}\text { Cerro Veladero } \\
\text { Granite }\end{array}$ & Late Carboniferous \\
\hline $\begin{array}{l}\text { Andean } \\
\text { Orogeny }\end{array}$ & & D5 & $\begin{array}{l}\text { Cuspade-lobate open D5 folds } \\
\text { with E-W high-angle axis plunge }\end{array}$ & & & Late Tertiary \\
\hline
\end{tabular}

Dykes of metasedimentary xenolith-rich leucocratic granites and protomylonitic granite were described in the northwestern area of the Sierra de Umango. These rocks define thin lens-shaped granite within the PFSZ (Figs. 3 and 4) and could represent the deformed equivalent of the Guandacolinos Granite.

The Cerro Veladero Granite outcrops in the south of Juchi Klippe (Fig. 3) and is dominated by subhypidiomorphic equigranular mediumgrained pinkish amphibole monzogranite that is rich in xenoliths and roof pendants of contact-metamorphosed sedimentary rocks.

\subsection{La Troya Marble}

This low-grade metasedimentary unit is tectonically juxtaposed between the PFSZ in the east and the Punilla Formation in the west (Figs. 3 and 6 ). The sequence corresponds to a tectonic slice composed of alternating light-brownish silicified meta-calcareous, slates and greyish to silvery phyllites. On the phyllitic planes, fanshaped minerals can be observed, and most of these minerals are weathered to fine-grained white mica. Minor feldspathic metasandstones and meta-conglomerates also occur.

Varela et al. (2011) compared these rocks with the Early Paleozoic marbles and para-amphibolites of Las Damas Marble in the northwestern parts of Jague (Martina and Astini, 2009). Lithologically, this unit is comparable either to the Ordovician strata (San Juan Formation or Trapiche Group) or the Cambrian strata (Cerro Totora Formation) of the Precordillera (Thomas and Astini, 2003) or to the Late Ediacaran to Cambrian rocks of Caucete Group in Sierra de Pie de Palo (Naipauer et al., 2010).

\subsection{Precordillera sedimentary rocks}

At the western limit of the Sierra de Umango units, a sedimentary sequence of the Western Precordillera, called the Punilla Formation, occurs (Fig. 3).
The Punilla Formation consists of continental and marine deposits from the Late Devonian to Early Carboniferous periods (Fauqué et al., 2004). This unit is folded on map-scale with a wavelength of synformal and antiformal folding of approximately $5 \mathrm{~km}$. A Cenozoic thrust fault and a left-lateral shear zone delimit its contact with La Troya Marble and the basement rocks of the Sierra de Umango.

\subsection{Sedimentary cover}

The sedimentary cover of the Sierra de Umango is composed of Late Paleozoic to Mesozoic rift-related sedimentary sequences and Cenozoic syn-orogenic deposits (Fig. 3).

Carboniferous to Permian sedimentary rocks of the Paganzo Basin rest unconformably over the Late Devonian folded siliciclastic deposits in the northwestern-most Sierra de Las Minitas and the basement rocks of the Sierra de Umango (Tambillo Unit at La Pereza Creek and southern limit of Juchi Orthogneiss). These sequences are represented by the Rio del Peñón and Panacán formations, respectively. The Panacán Formation at southern Juchi Creek consists of reddish to light feldspathic sandstones and dark conglomeratic sandstone. A reverse fault was observed deforming these psammite rocks.

Cretaceous rocks of the Ciénaga del Rio Huaco Formation are mostly composed of sandstones, conglomerates, pelites and evaporites and rest unconformably over the Panacán Formation (Fauqué et al., 2004).

A syn-orogenic Cenozoic sedimentary sequence separates the rocks of the Sierra de Umango from the basement rocks of the Sierra del Espinal and Sierra de Maz.

\section{Structures of the Sierra de Umango}

The polyphase structural evolution of the Sierra de Umango involved five deformational phases related to three diachronous 
tectonic events (Table 1). These deformational phases were determined by fieldwork observations of the folds' characteristics and their interference patterns (Fig. 10 and descriptions below) and also by the interpretation of the stereograms (Figs. 5, 7 and 9).

The first three deformational phases (D1, D2 and D3) are interpreted to correspond to the main phase of the Famatinian Orogeny on basis of geochronological data reviewed by Varela et al. (2011) and are correlated with the development of a Nappe System associated with an oblique collisional event. The Nappe System concept in the Sierra de Umango follows the discussion published in McClay and Price (1981), which defined "a fold nappe" as "an allochthonous tectonic unit which exhibits large-scale stratigraphic inversion and may have initiated from large recumbent folds. The underlying limbs of these folds may be sheared out into thrust faults" and form klippe where these become isolated. The klippen of the Juchi Orthogneiss basement unit represent the large-scale stratigraphic inversion and its limit with the underlying Tambillo unit is characterized by a ductile thrust fault (Fig. 11a and b).

Two subsequent deformational events affected the Famatinian structures. The D4 deformational phase is correlated with the lateto post-orogenic phase of the Famatinian Orogeny (Chanica Phase) and was characterised by $\sim \mathrm{N}-\mathrm{S}$ open and closed upright folds and discrete sinistral protomylonitic shear zones (Fig. 11d). The D5 deformational phase was marked by $\mathrm{E}-\mathrm{W}$ open, steeply plunging folds possibly associated with the Andean Orogeny (Fig. 11e).

In the following subsections, the structures that resulted from various events in the Sierra de Umango, from the Ordovician period to the Cenozoic era, are described in detail.

\subsection{Ordovician structures}

The main metamorphic structure of the Sierra de Umango basement rocks is defined by a transposition or mylonitic foliation, S2. This structure was formed in a collisional event that developed a Nappe System and an important shear zone (PFSZ) and it was dated in a range from $452 \pm 11$ to $474 \pm 12 \mathrm{Ma}$ (Varela et al., 2011). A continuous sequence of deformational phases (D1, D2 and D3) and accompanying metamorphism define this collisional event (Porcher et al., 2004; Meira, 2010; Varela et al., 2011). D1 likely corresponds to the prograde metamorphic stage; D2 exhibits P-T conditions close to the metamorphic peak; and D3 likely includes the retrograde metamorphic stage with growing of fine-grained muscovite and biotite in the S3. The metamorphism related to these deformations resulted in up to medium- to high-pressure granulite to upper amphibolite facies conditions, characterized by the paragenesis Ky/Sil-Grt-KFs-Rt-Qtz in metapelites (Meira, 2010) and Grt-Di-Amp-Pl(oligoclase to andesine)-Ilm-Rt in metabasic rocks (González et al., 2005).

Previous studies (Fernandes et al., 2001, 2002; Porcher et al., 2004) have described four folding phases (F1, F2, F3 and F4) that

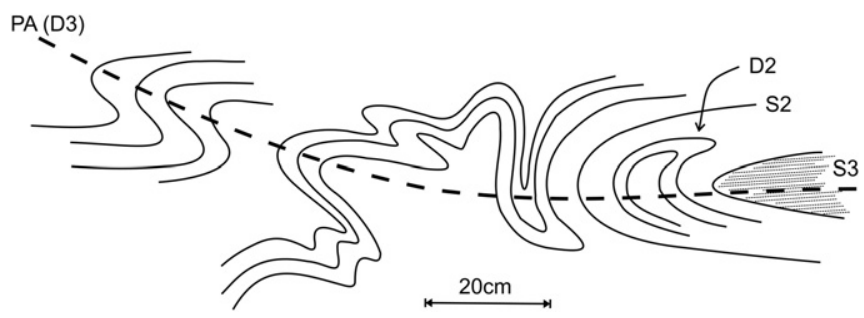

Fig. 10. Folding interference pattern observed on calcsilicate rocks from the Tambillo Unit. Note that the D2 folds are deformed by D3 recumbent to inclined assymetric folds. The D3 axial plane is also deformed by a later open upright folding (D4 folds). affected the rocks in the Maz, Espinal, Las Ramaditas and Umango ranges. The F1, F2 (isoclinal to tight folds) and composite banding were associated with the main event recorded in these rocks. These structures are correlated with D2 folds and S2 foliation of this work. The F3 and F4 phases likely represent younger deformations and will be discussed in the next sections.

The relic foliation, $\mathrm{S} 1$, is recognised mainly in the hinge zones of intrafolial and isoclinal D2 folds and is highlighted by intercalations of amphibolites and marbles (Fig. 12a and b). Asymmetric intrafolial folds delineated by quartz veinlets and, occasionally, by composite banding, also define the $\mathrm{S} 1$ foliation. The scarcity of these structures prevents spatial and geometric analyses. In thin sections, S1 appears as internal foliation within staurolite interkinematic porphyroblasts (Fig. 12c), suggesting continuous deformational and metamorphic patterns between S1 and S2.

The main foliation, S2, is associated with an originally flat-lying fabric, mostly defined by the orientation of micaceous minerals and amphibole, which are usually parallel to the composite banding and related to the axial planes of intrafolial folds (Fig. 12b and d). The isoclinal intrafolial folds (D2) can be observed in mesoscopic (outcrops) and macroscopic (satellite images - see Fig. 3) scales. Sheath folds (Fig. 13), boudins and pinch-and-swell structures are also linked to the D2 fabric. In the PFSZ, the main foliation corresponds to a mylonitic to protomylonitic foliation, mainly delineated by biotite-rich bands and quartz ribbons, which commonly contain pre- to syn-kinematic garnet porphyroblasts and porphyroclasts (Fig. 14a), as well as feldspar porphyroclasts (Fig. 14b). This structure is correlated with the D2 deformation. Stretching and mineral lineations lying in $\mathrm{S} 2$ predominantly have a trend between $\mathrm{N}-\mathrm{S}$ or NW-SE and NE-SW. The L2 mullions and D2 axes are generally sub-parallel to the stretching lineations. The kinematic indicators include mesoscopic and microscopic porphyroclasts and suggest major movement with top-to-the S/SW, with minor top-to-the SE sense direction, parallel to the approximately $\mathrm{N}-\mathrm{S}$ trending lineations (Fig. 14c and d).

At least three folding phases deformed the D2 structures and produced different interference and dispersal patterns. Two major pole dispersal patterns were recognised: an E-W pattern, associated with D4 folding, and an $\mathrm{N}-\mathrm{S}$ pattern, related to D5 folding (Figs. 5, 7 and 9). These dispersal patterns are detailed in the next sections.

Close-to-tight asymmetric and inclined-to-recumbent folds were detected deforming the S2 foliation (Figs. 10 and 14e and f) and were associated to the D3 folds. These folds are generally associated with axial plane schistosity (S3) marked by aligned finegrained mica (Fig. 14f) and thrust faults along the overturned limbs (Fig. 15a). The spatial control of D3 folds is poorly understood, but the available data suggest an axial plane trending in the NW-SE direction and dipping gently to steeply in the NE direction (Fig. 9C-F).

In general, the structure of the collisional event comprises the Juchi Orthogneiss klippen, which were overthrusted onto the Tambillo Unit to the S-SW. In the west, the structure related to the collisional event is bounded by a right lateral shear zone (PFSZ) that acted as a lateral ramp. This collisional event was related to the accretion of the Cuyania Terrane to the protoAndean margin of Gondwana during the Ordovician period. The available geochronological data (Varela et al., 2003a,b, 2008, 2011 ) indicate a range from $452 \pm 11$ to $487 \pm 1 \mathrm{Ma}$ for the collisional event (ages constrained by $\mathrm{U} / \mathrm{Pb}$ in monazite from paragneisses in the PFSZ and TIMS U/Pb in zircon from biotite orthogneisses of the El Peñon Granite, respectively), in accordance with the data of Voldman et al. (2008), which provided evidences for metamorphism during the Early to Middle Ordovician in the Precordillera. 


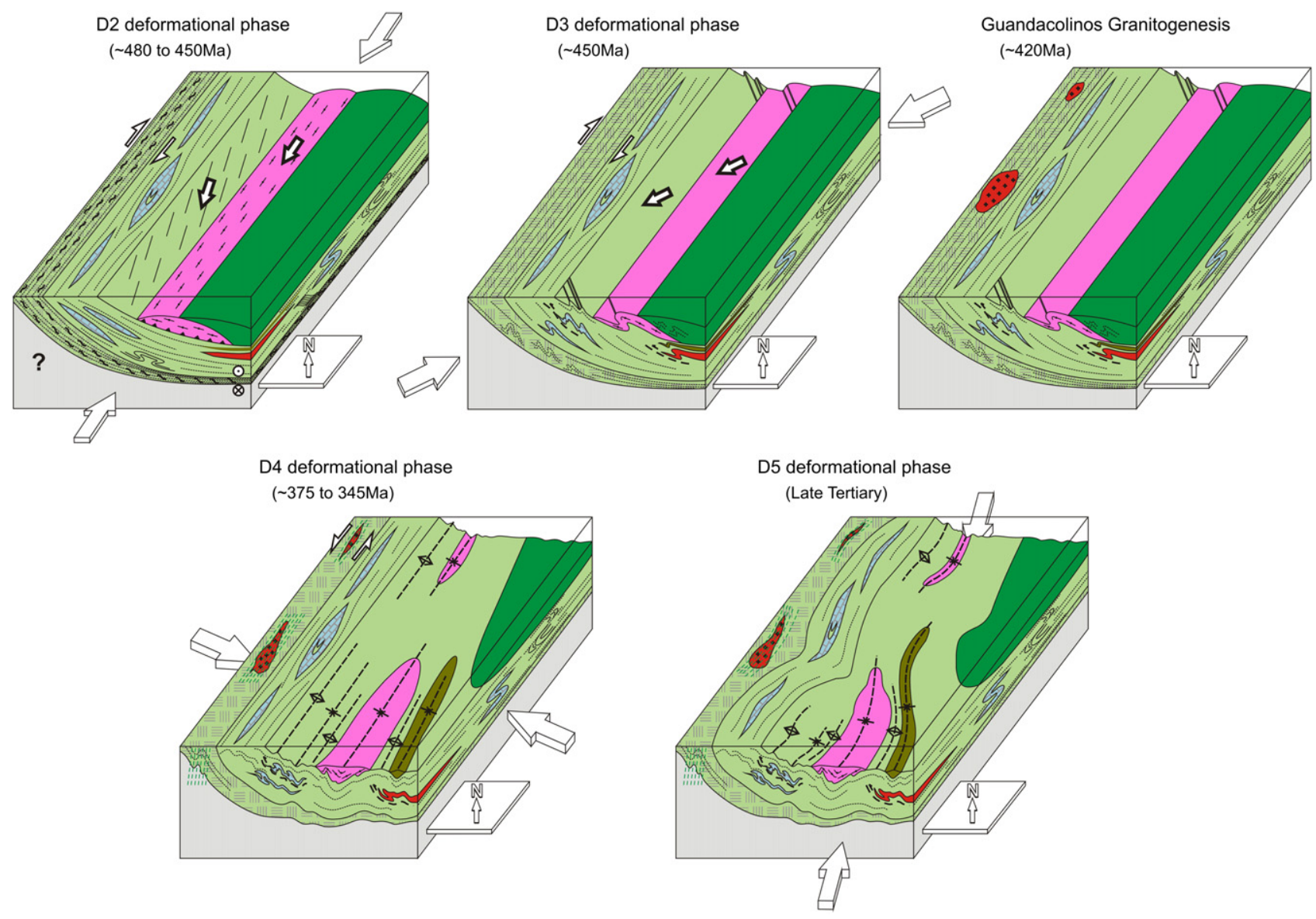

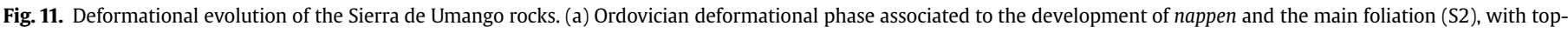

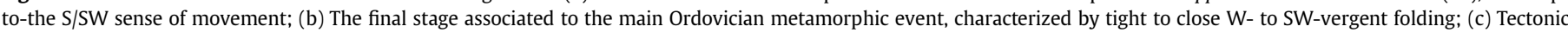

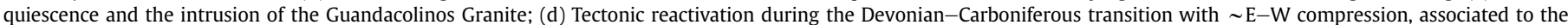

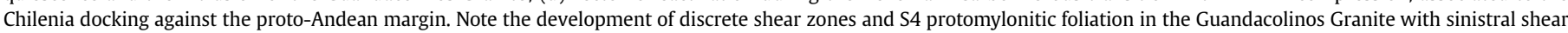

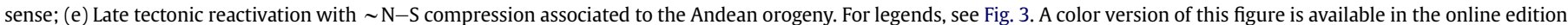

\subsection{Devonian structures}

A subsequent deformation phase (D4) affected the Sierra de Umango basement rocks, the Guandacolinos Granite and the Punilla Formation. This deformation is attributed to the open-toclosed, upright-to-E-vergent folds (D4 folds) oriented in the $\mathrm{N}-\mathrm{S}$ to NE-SW directions (Fig. 15b-d). This phase could be correlated with the F3 folds described by Fernandes et al. (2001), (2002) and Porcher et al. (2004). These folds are responsible for the $\mathrm{E}-\mathrm{W}$ pole dispersal pattern of the main metamorphic foliation (S2) that controls the main orientation of the S2 surface in the Sierra de Umango. This dispersal pattern (Fig. 5-II A, B and E-G; Fig. 7-I A-C; Fig. 7-II A-C; Fig. 9A-K) indicates a nearly cylindrical geometry for the D4 folds and assumes that the S2 foliation was originally a shallowly-dipping surface. The D4 folding corresponds to a flexural fold with concentration of the deformation in the limbs, a wavelength varying from 5 to $10 \mathrm{~km}$ and an amplitude of approximately $1 \mathrm{~km}$ (Fig. 8). The map-scale folding defined by the outcrop pattern of the La Punilla Formation (Fig. 3 - Sierra de La Punilla and Sierra de Las Minitas) is thought to be related to these structures. Discrete shear zones, marked by protomylonitic foliation within the Guandacolinos Granite, trend sub-parallel to the axial plane of the D4 folds (Figs. 6-I and 7-I C-F) and were correlated with this deformational phase. A left-lateral (sinistral) kinematic, determined at the protomylonitic shear zone, affected the lens-shaped granite in the northwestern region of the Sierra de Umango (Fig. 14e and f).

Two geological features reveal important clues about the timing of this deformation: 1) the discrete shear zones affected the Guandacolinos Granite and did not deform the Cerro Veladero Granite and 2) the deformation occurred after the deposition of the La Punilla Formation in Sierra de Las Minitas and before the deposition of the Rio del Peñon Formation in the northwesternmost region of Sierra de Las Minitas.

Distinct ages were obtained for the Guandacolinos Granite in the last fifteen years. The first radiometric data indicate a Late Devonian/Early Carboniferous age ( $\mathrm{Rb} / \mathrm{Sr}$ whole rock isochron Varela et al., 1996), although newer $\mathrm{Rb} / \mathrm{Sr}$ whole rock and $\mathrm{U} / \mathrm{Pb}$ TIMS studies (Varela et al., 2005) pointed to the intrusion of Guandacolinos Granite during the Late Carboniferous period ( $\mathrm{Rb} / \mathrm{Sr}$ whole rock errochron of $324 \pm 36 \mathrm{Ma}$ and U/Pb TIMS in zircons of $314 \pm 14 \mathrm{Ma}$ ). A recent SHRIMP U/Pb zircon aging study (unpublished data) revealed Silurian core ages and Devonian rim ages for zircon from the Guandacolinos Granite (Basei, personal communication). Cingolani et al. (1993) dated the Cerro Veladero Granite and determined an age of $311 \pm 14 \mathrm{Ma}$ for its crystallisation.

Based on palaeoflora, the depositional age of Punilla Formation is considered to be from the Late Devonian to Early Carboniferous 

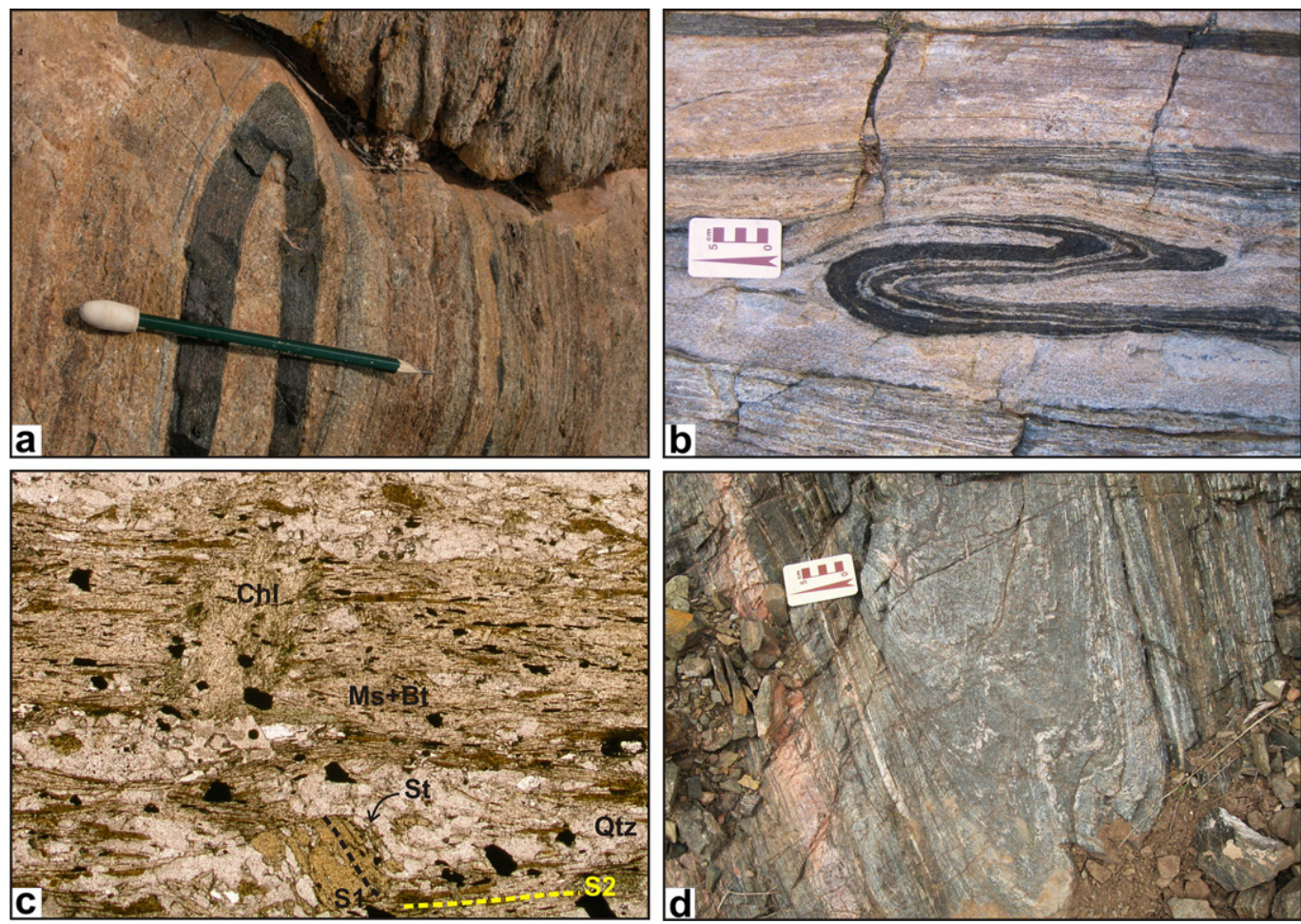

Fig. 12. Photographs of the $\mathrm{S} 1$ relics and the $\mathrm{D} 2$ isoclinal folds. (a) Intrafolial and isoclinal fold (D2), delineated by a $2 \mathrm{~cm}$-thick amphibolite layer (Tambillo Unit - Barreal Grande area). Note that the internal foliation S1 is folded and transposed by the D2 fold and S2 foliation; (b) Rootless intrafolial and isoclinal fold (D2) defined by relics of S1 foliation within thin amphibolite and marble intercalations (Tambillo Unit - Umango River); (c) Photomicrography of biotite-opaque-muscovite schist with chlorite and staurolite porphyroblasts (Tambillito Unit). The staurolite porphyroblast attests the presence of an internal foliation (S1), suggesting an interkinematic growth (the long edge of the image is approximately $5 \mathrm{~mm}$ ); (d) Intrafolial and isoclinal fold (D2) in banded biotite gneiss (Juchi Orthogneiss - La Falda Klippe).

periods (Caminos and Fauqué, 1999; Azcuy et al., 1999 and references therein). The Rio del Peñon Formation was deposited in the Late Carboniferous period (Caminos and Fauqué, 1999; Azcuy et al., 1999 and references therein) and overlain discordantly above a Devonian sequence of folded sedimentary rocks (Carrizo, 1998; Carrizo and Azcuy, 1995, 1997). According to these data, the deformational phase (D4) occurred between the Devonian and Late Carboniferous periods.
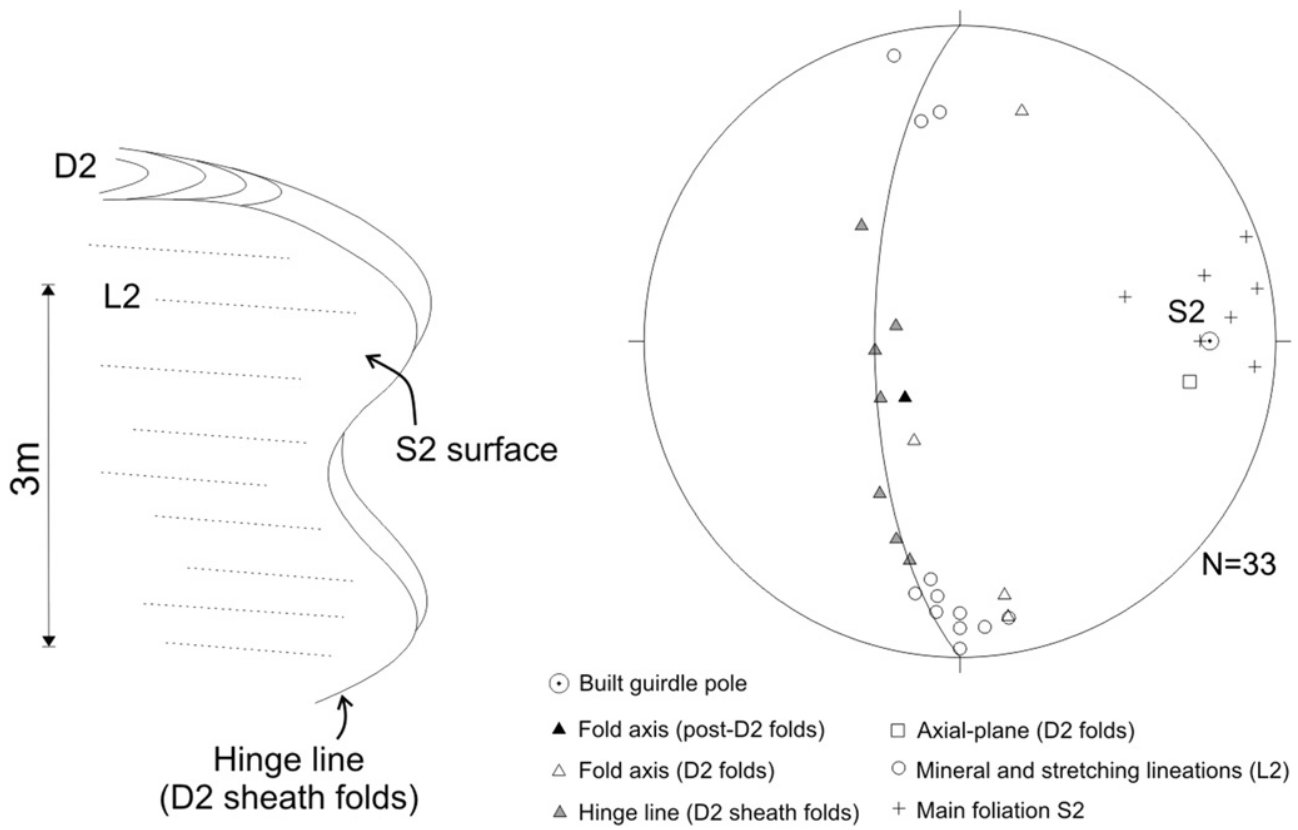

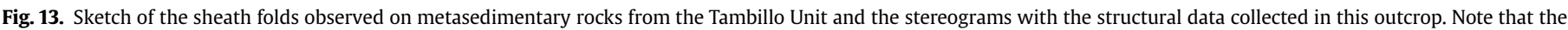
built guirdle pole is coincident with the S2 foliation pole. 

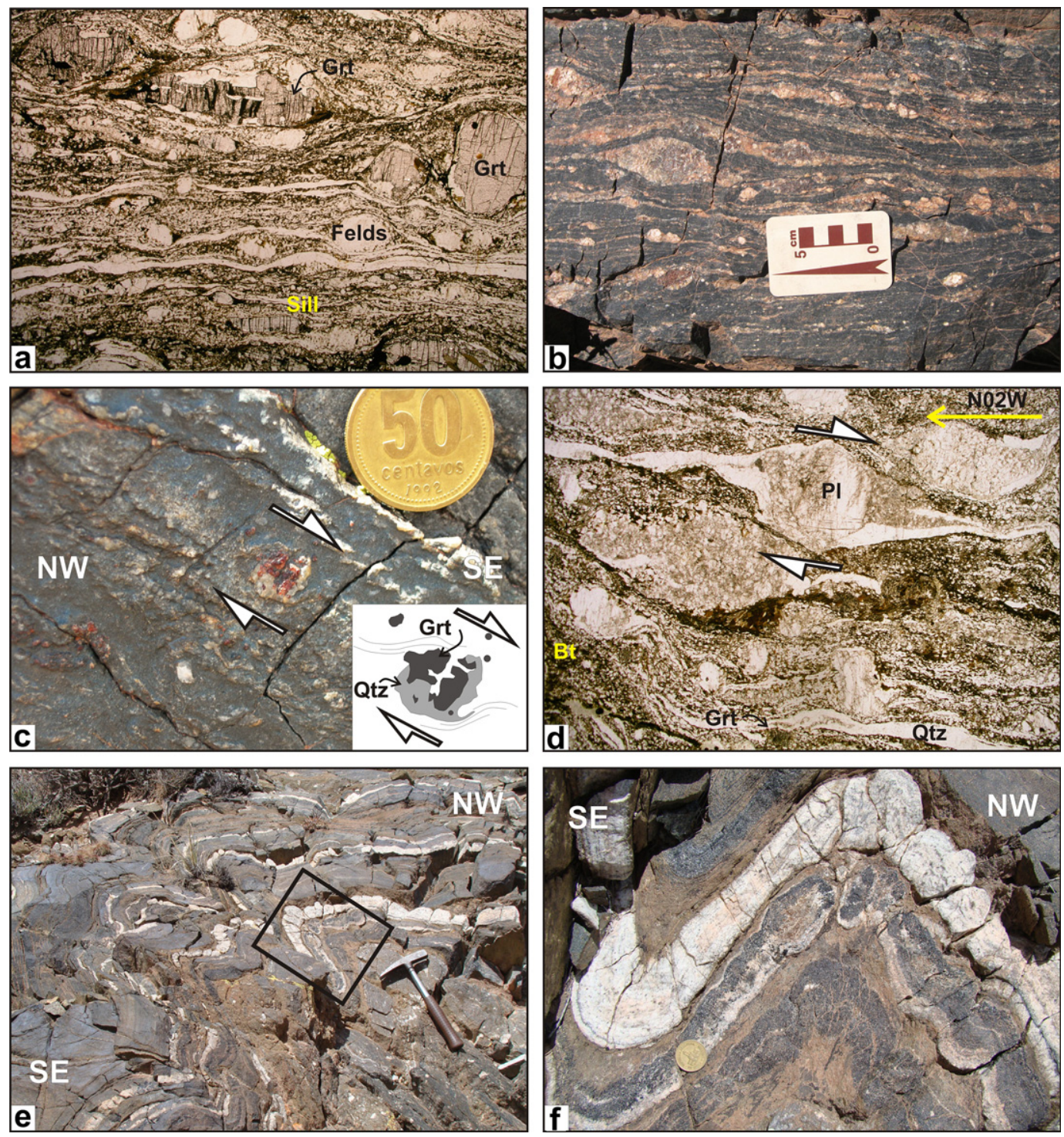

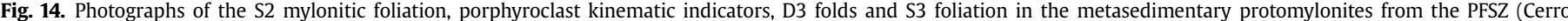

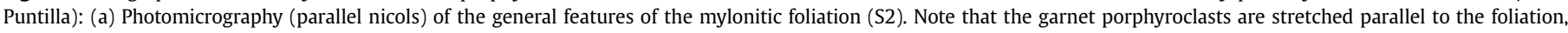

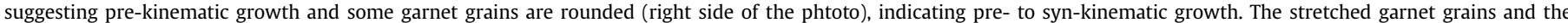

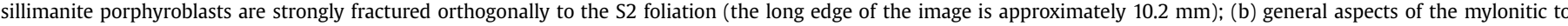

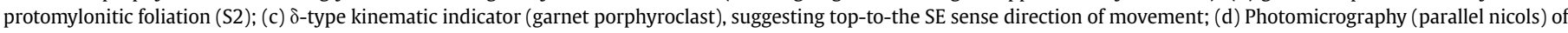

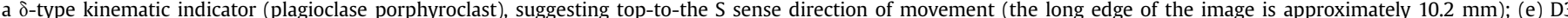

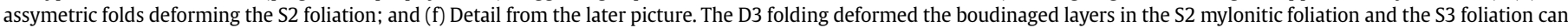
be observed in the metapelitic layers.

\subsection{Late Tertiary structures}

The last recognised deformational phase (D5) in the study area is related to cuspate-lobate shaped open plunging folds with $\mathrm{E}-\mathrm{W}$ high-angle axes (Fig. 15g). The sigmoidal contours of the mapped units, as shown in the PFSZ outline, seem to be associated with this folding phase. The stereograms and the $\mathrm{N}-\mathrm{S}$ dispersal pattern of $\mathrm{L} 2$ lineation and S2 foliation poles (Figs. 5-I B, II C and D, 7-I C-E and F, II $A$ and $9 \mathrm{~J}$ and $\mathrm{K}$ ) suggest the existence of the D5 deformation.

Fold- and thrust-deformed sedimentary rocks of foreland Tertiary basins are shown at the map-scale (Fig. 2). This deformation is attributed to the syn-orogenic deposits of the Andean tectonics during the Late Miocene to Pliocene epochs and was controlled by the uplifting of the Frontal Cordillera and Western Sierras Pampeanas in this region of Andean Cordillera (Ramos, 1999c and references therein). A Type 1 dome and basin interference pattern deformed the tertiary rocks (southwestern Fig. 2). This has been interpreted as two folding phases of Andean Orogeny; the earlier fold belongs to the D5 deformational phase, and the $\mathrm{N}-\mathrm{S}$ trending folds and thrusts correspond to the later Andean Late Tertiary deformation.

\section{Discussion and geotectonic implications}

The polyphase structural evolution of the Western Sierras Pampeanas has been mentioned by Hausen (1921), De Alba (1954), Turner (1964), Furqué (1972), and Kilmurray and Dalla Salda (1971), among others.

In the Western Sierras Pampeanas, the Ordovician deformation and metamorphism are attributed to the accretion of the Cuyania 

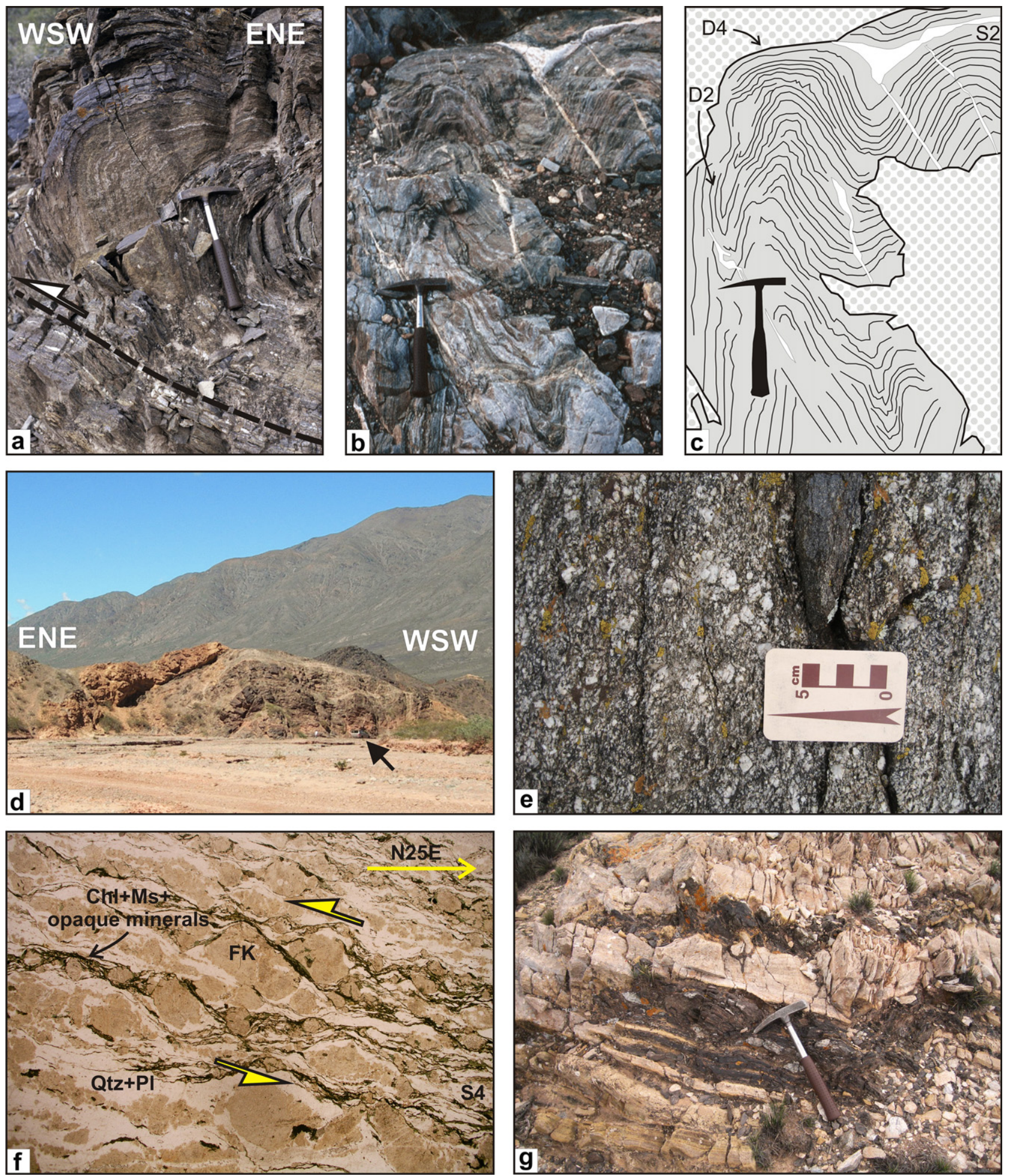

Fig. 15. Photographs of D3 and D4 folds, S4 protomylonitic foliation and D5 folds. (a) D3 recumbent folds with a disrupted limb verging to the W/SW direction and associated with thrust fault in brownish schist intercalated with thin quartz-rich ribbons (Tambillo Unit - Quebrada Amarilla); (b and c) Type 3 divergent-convergent folding interference pattern in greyish metamarls intercalated with thin layers of brownish calcic pelitic rocks, showing S2 foliation and D2 tight folds deformed by D4 open upright folds (Tambillo Unit Quebrada La Champa); (d) D4 open upright folds trending N-S in intercalations of light yellowish breccia marbles and dark pelitic mylonites (PFSZ - Cerro La Puntilla). The arrow indicates a truck as a graphic scale. In the foreground sets the La Troya River and the Sierra de La Punilla stands in the background; (e) Protomylonitic leucocratic coarse-grained inequigranular granite showing the general character of S4 protomylonitic foliation (Guandacolinos Granite); (f) Photomicrography (parallel nicols) of muscovite-chlorite protomylonitic granite (oriented thin section from the rock of the last photo), with S4 protomylonitic foliation defined by thin discontinuous lepidoblastic bands of chlorite, muscovite and opaque minerals, and feldspar porphyroclasts. Domino-type and $\sigma$-type kinematic indicators suggest left-lateral kinematic movement toward the discrete shear zones (D4 protomylonitic foliation); (g) Cuspade-lobate open D5 folds and sub-vertical spaced cleavage in intercalations of marble and amphibolite layers (Tambillo Unit - Barreal Chico surroundings). 
Terrane onto the southwestern part of Gondwana (see synthesis in Ramos et al., 1998). At the Sierra de Umango, the main metamorphic structures are interpreted to belong to this collisional event, which is characterised by three continuous deformational phases (D1, D2 and D3). These deformational phases may record the prograde metamorphism (D1), the P-T conditions close to the metamorphic peak with thickened crust (D2) and the retrograde metamorphism with partial exhumation (D3). This event lasted at least 30 million years, nearly the entire Ordovician period (from $\sim 480$ to $\sim 450 \mathrm{Ma}$ - Varela et al., 2003a,b, 2008; Voldman et al., 2008). In the D2 deformational phase, the metamorphic conditions produced medium- to high-P granulite facies (Juchi Orthogneiss and PFSZ) (Porcher et al., 2004; González et al., 2005), medium-P amphibolite facies (Tambillo Unit) and medium-P lower amphibolite and greenschist facies (Tambillito Unit), consistent with collisional settings and continental wedge subduction (Meira, 2010). The extrusion of the subducted continental wedge occurred in a Nappe System and was facilitated by Lateral Shear Zones (e.g., PFSZ) until the development of conditions that produced lower amphibolite-to-greenschist facies (D3 phase).

In the Western Sierras Pampeanas, Nappe structures were also recognized and described in the Sierra de Pie de Palo by Ramos et al. (1996) and, more recently, by van Staal et al. (2011), Mulcahy et al. (2011) and references therein. These authors cited the Ordovician collisional history to explain the nappen structures (van Staal et al., 2011) and the composite middle to lower crustal section (Mulcahy et al., 2011).

Although it was once accepted as a scientific fact, discussions about the character and kinematic nature of this collision are ongoing. The results of this study suggest an oblique collision involving the northeastern subduction of the Cuyania Terrane under the proto-Andean margin of Gondwana. The subduction direction was inferred from the syn-metamorphic extrusion, registered on the nappen (top- to-S/SW) and on the PFSZ (right lateral shear zone), even so minor top-to-the $\mathrm{N}$ kinematic indicators occur in the surroundings of the Cerro Cacho (Fernandes et al., 2001, 2002; Porcher et al., 2004; Meira, 2010). Conversely, kinematic evidence from Puna, Sierra de Pie de Palo and Eastern Sierras Pampeanas is compatible with an E-W compression (top-to-the W sense) and an orthogonal collision in the Famatinian collisional event (e.g., Le Corre and Rossello, 1994; Martino, 2003; Simpson et al., 2003; van Staal et al., 2011).

Radiometric data from El Peñon Granite, interpreted as a pre- to syn-collisional granite, corroborate to the Early Ordovician magmatism associated to the evolution of the Famatinian Magmatic Arc (e.g., Dahlquist et al., 2007, 2008) and the Early to Middle Ordovician ductile deformation during the collisional event (Varela et al., 2000, 2008; Voldman et al., 2008). However, the crystallisation age of El Cordobés-related basic rocks is still debated. Sm/Nd data (whole rock, plagioclase and amphibole) from amphibolites of the Barreal Grande region reveal Devonian ages (392 $\pm 50 \mathrm{Ma}$ - Varela et al., 2002), while zircon TIMS U/Pb data from the same area suggest older ages (446 $\pm 3 \mathrm{Ma}$ - Varela et al., 2008). Varela et al. $(2002,2008)$ proposed that the El Cordobés Unit, together with the swarm pegmatites (well exposed in the Umango River section), represent the Chanica Tectonics effects at the Sierra de Umango, though Varela et al. (2011) did not discard the possibility that these ages correspond to metamorphic overprints of an older igneous unit (Mesoproterozoic-age basic rocks?).

Tectonic reactivation is marked by the D4 deformational phase, which includes discrete shear zones and the N-S to NE-SW trending open upright folds that affect the Punilla Formation, Guandacolinos Granite and Umango basement rocks. This deformation presumably occurred at a shallow crustal level with sinistral transpressional kinematic activity. As previously mentioned, geological evidence has shown that D4 deformation would have occurred prior to the Late Carboniferous period (deposition of Rio del Peñón Formation). Varela et al. (2005) proposed that the Guandacolinos Granite deformation was of an intra-Carboniferous age (between 314 and $311 \mathrm{Ma}$ ). The authors agreed with the proposal of intra-Carboniferous tectonic movement in the Punilla Formation (Rio Blanco tectonic phase of Fauqué et al., 1999). Nonetheless, Azcuy et al. (1999) opposed the idea of the Rio Blanco tectonic phase, arguing that the sedimentary interval described by Fauqué et al. (1999) represents a transitional deposition in the Punilla Formation. Based on the SHRIMP $\mathrm{U} / \mathrm{Pb}$ zircon age (Basei, personal communication) of the Silurian core (crystallisation age) and the Devonian rim (metamorphism?), the D4 deformational phase must have occurred during the Late Devonian period associated with the late- to post-orogenic phase of the Famatinian Orogeny (Chanica Phase), in agreement with Azcuy et al. (1999) and Varela et al. (2002). A Devonian sinistral transpressional event was also described in the Sierra de San Luis (von Gosen, 1998). This tectonic reactivation could be related with the collision of Chilenia Terrane onto the western margin of Gondwana (c.f. Ramos et al., 1998; Quernadelle and Ramos, 1999; Ramos, 1999b).

The uplifting of the basement outcrops at the Sierras Pampeanas occurred during the Late Cenozoic era in the Andean Orogeny and was likely reactivated by several pre-existent structures (Ramos et al., 2002). This deformation geometrically modified the Ordovician structures, which mainly resulted in the tilting of major blocks (c.f., Fig. 4b in Ramos et al., 2002). The D5 deformational phase described herein could be related to the Andean Orogeny.

\section{Concluding remarks}

A polyphase structural evolution process was identified at the Sierra de Umango. The Famatinian collisional event is defined by a Nappe System, the clearly delineated Mesoproterozoic Juchi Orthogneiss klippen, and an important shear zone (PFSZ) along the western boundary of the Sierra de Umango. The Nappe System revealed a top-to-the S/SW sense direction of movement and the PFSZ served as a right lateral ramp facilitating the exhumation process (Fig. 11a). An oblique collision is hypothesised, with the Cuyania Terrane subducting underneath the proto-Andean margin of Gondwana in the NE direction. The continental subduction and exhumation lasted at least 30 M.y., nearly the entire Ordovician period, and resulted in metamorphic conditions that produced upper amphibolite-to-granulite facies in medium- to high-pressure regimes. The El Peñon Granite exemplifies the pre- to syncollisional granitoid intrusions. In the Silurian, a granitogenesis (Guandacolinos Granite intrusion - Fig. 11c) occurred that was possibly associated with the westward migration of the subduction. Compressive tectonic reactivation (Chanica tectonic phase), related to the Devonian accretion of the Chilenia Terrane along the Western margin of Gondwana, affected the previously deformed rocks, the Devonian sedimentary rocks of Precordillera (Punilla Formation) and the Guandacolinos Granite (Fig. 11d). The Chanica tectonic phase in the Sierra de Umango and the surroundings is characterised by the presence of open folds in the $\mathrm{N}-\mathrm{S}$ direction and by sinistral discrete shear zones. Late Carboniferous post-collisional magmatism (Cerro Veladero Granite) intruded in the southern portion of the Umango basement rocks and is linked to the Gondwanic Tectonic Cycle. Extensional tectonics and deposition of Carboniferous/Permian sediments (e.g., Paganzo Basin) and Triassic deposits (Ischigualasto Basin) are also typical of the Gondwanic Cycle. Cretaceous extensional retroarc basins and Tertiary foreland basins are indicative of the Andean Orogeny. An approximately $\mathrm{N}-\mathrm{S}$ 
compressional regime (Fig. 11e) preceded the usual E-W shortening of the Andean tectonics.

\section{Acknowledgements}

This research has been supported by the Fundação de Amparo à Pesquisa do Estado de São Paulo (FAPESP-2006/06957-1). Marcial and Rosendo Pérez and relatives, Juan Arancibia and Ramón Urriche and their "mulas" were an essential help during the fieldwork. The first author is very thankful for all support given by Thaís Hyppolito. We are grateful for the comments and suggestions of two anonymous reviewers, which greatly improved the original manuscript.

\section{References}

Aceñolanza, F.G., Toselli, A.J., 1988. El Sistema de Famatina, Argentina: su interpretación como orógeno de margen continental activo. In: V Congreso Geologico Chileno, vol. 1, pp. 55-67.

Aceñolanza, F.G., Miller, H., Toselli, A.J., 2002. Proterozoic-Early Paleozoic evolution in western South America: a discussion. Tectonophysics 354, 121-137.

Allmendinger, R.W., Figueroa, D., Snyder, D., Beer, J., Mpodozis, C., Isacks, B.L., 1990. Foreland shortening and crustal balancing in the Andes at $30^{\circ} \mathrm{S}$ latitude. Tectonics 9, 789-809.

Azcuy, C.L., Carrizo, H.A., Caminos, R., 1999. Carbonífero y Pérmico da las Sierras Pampeanas, Famatina, Precordillera, Cordillera Frontal y Bloque de San Rafael. In: Caminos, R. (Ed.), Geologia Argentina. Servicio Geológico Minero Argentino, Anais, vol. 29, pp. 261-318.

Baldis, B.A., Beresi, M.S., Bordonaro, O., Vaca, A., 1984. The Argentine Precordillera as a key to the Andean structure. Episodes 17, 14-19.

Baldis, B.A., Peralta, S.H., Villegas, R., 1989. Esquematizaciones de una posible transcurrencia del terrane de Precordillera como fragmento continental procedente de areas pampeano-bonaerenses, Universidad Nacional de Tucumán. Serie Correlaciones Geológicas 5, 81-100.

Benedetto, J.L., 2004. The allochthony of the Argentine Precordillera ten years later (1993-2003): a new paleobiogeographic test of the microcontinent model. Gondwana Research 7, 1027-1039.

Caminos, R., Fauqué, L., 1999. Hoja Geológica 2969-II Tinogasta, La Rioja y Catamarca, Boletin No. 276. Instituto de Geologia y Recursos Minerales (Servicio Geológico Minero Argentino).

Caminos, R., 1979. Sierras Pampeanas Noroccidentales. Salta, Tucumán, Catamarca, La Rioja y San Juan. In: Turner, J. (Ed.), II Simposio de Geología Regional Argentina, vol. 1. Academia Nacional de Ciencias de Córdoba, pp. 225-291.

Carrizo, H.A., Azcuy, C.L., 1995. La zona MBG (Carbonífero Tardío) en las inmediaciones del río Agua de Carlos, La Rioja, Argentina. Ameghiniana 32, 271-278.

Carrizo, H.A., Azcuy, C.L., 1997. Las fitozonas del Carbonífero temprano de Argentin y la edad de las discordancias relacionadas: una discusión. IX Reunião de Paleobotânicos e palinólogos. Revista Universidade Guarulhos, São Paulo, Serie Geociências 2 (special number), 19-27.

Carrizo, H.A., 1998. Estudio de floras eocarboníferas de Argentina y su comparación con las de otras regiones relacionadas. Unpublished Doctoral Thesis. Universidad Nacional de Salta.

Casquet, C., Pankhurst, R.J., Fanning, C.M., Baldo, E., Galindo, C., Rapela, C.W., González-Casado, J.M., Dahlquist, J.A., 2006. U/Pb SHRIMP zircon dating of Grenvillian metamorphism in Western Sierras Pampeanas (Argentina): correlation with the Arequipa Antofalla craton and constraints on the extent of the Precordillera Terrane. Gondwana Research 9, 524-529.

Casquet, C., Pankhurst, R.J., Rapela, C., Galindo, C., Fanning, C.M., Chiaradia, M. Baldo, E., González-Casado, J.M., Dahlquist, J.A., 2008. The Maz terrane: a Mesoproterozoic domain in the western Sierras Pampeanas (Argentina) equivalen to the Arequipa-Antofalla block of southern Perú? Implications for Western Gondwana margin evolution. Gondwana Research 13, 163-175.

Cingolani, C., Varela, R., Dalla Salda, L., Kawashita, K., 1993. Los granitoides del cerro Veladero, río de la Troya, provincia de La Rioja: estudio geocronológico e implicancias tectónicas. In: XII Congreso Geológico Argentino and II Congreso de Exploración de Hidrocarburos, vol. 4, pp. 68-74.

Coira, B., Davidson, J., Mpodozis, C., Ramos, V., 1982. Tectonic and magmatic evolution of the Andes of Northern Argentina and Chile. Earth-Science Reviews $18,303-332$.

Coney, P.J., Jones, D.L., Monger, J.W.H., 1980. Cordilleran suspects terranes. Nature $288,303-333$.

Dahlquist, J.A., Galindo, C., Pankhurst, R.J., Rapela, C.W., Alasino, P.H., Saavedra, J. Fanning, C.M., 2007. Magmatic evolution of the Peñón Rosado granite: petrogenesis of garnet-bearing granitoids. Lithos 95, 177-207.

Dahlquist, J.A., Pankhurst, R.J., Rapela, C.W., Galindo, C., Alasino, P.H., Fanning, C.M., Saavedra, J., Baldo, E., 2008. New SHRIMP U-Pb data from the Famatina Complex: constraining Early-Mid Ordovician Famatinian magmatism in the Sierras Pampeanas, Argentina. Geologica Acta 6, 319-333.

Dalla Salda, L., Cingolani, C., Varela, R., 1992a. Early Paleozoic orogenic belt of the Andes in southwestern South America: result of Laurentia-Gondwana collision? Geology 20, 617-620.
Dalla Salda, L., Dalziel, I.W.D., Cingolani, C., Varela, R., 1992b. Did the Taconic Appalachians continue into southern South America? Geology 20, 1059-1062.

Dalziel, I.W.D., Dalla Salda, L.H., Gahagan, L.M., 1994. Paleozoic Laurentia-Gondwana interaction and the origin of the Appalachian-Andean mountain system. Geological Society of America Bulletin 106, 243-252.

Dalziel, I.W.D., 1997. Overview: Neoproterozoic-Paleozoic geography and tectonics: review, hypothesis, environmental speculation. Geological Society of America Bulletin 109, 16-42.

De Alba, E., 1954. Descripción geológica de la Hoja 16c, Villa Unión. Boletín de la Dirección Nacional de Geología y Minería 82, 1-81.

Fauqué, L., Limarino, O., Cingolani, C., Varela, R., 1999. Los movimientos intracarboníferos en la Precordillera riojana. In: XIV Congreso Geológico Argentino, vol. 1 , pp. 421-424.

Fauqué, L., Limarino, C., Vujovich, G., Fernandes, L.A.D., Cegarra, M., Ecosteguy, L., 2004. Hoja Geológica 2969-IV Villa Unión, La Rioja y San Juan, Boletin No. 345. Instituto de Geologia y Recursos Minerales (Servicio Geologico Minero Argentino).

Fernandes, L.A.D., Porcher, C.C., Vujovich, G.I., Escosteguy, L.D., Morales, L.F.G., 2001 Geologia estructural de los gneises de las Sierras de Maz Y Umango, La Rioja, Argentina: Datos preliminares. In: XI Congresso Latinoamericano de Geologia, Montevidéo.

Fernandes, L.A.D., Porcher, C.C., Vujovich, G.I., Silva, A.M.O., Escosteguy, L.D. Fauqué, L., Morales, L.F.G., 2002. Geologia estructural e termobarometria dos gnaisses das Serras Pampeanas do NW e suas implicações na evolução tectônica da Precordilheira argentina. In: XV Congreso Geológico Argentino, vol. 2, pp. 188-192.

Finney, S., Gleason, J., Gehrels, G., Peralta, S., Aceñolanza, G., 2003. Early Gondwanan connection for Argentina Precordillera terrane. Earth and Planetary Sciences Letters 205, 349-359.

Furqué, G., 1972. Descripción Geológica de la Hoja 16b, Cerro La Bolsa, Provincia de La Rioja y San Juan. Servicio Nacional Minerio y Geológico, Boletín 125, 1-69. Buenos Aires.

Gansser, A., 1973. Facts and theories on the Andes. Journal of the Geological Society of London 129, 93-131.

González, P.D., Varela, R., Vlach, S., 2005. Eclogite to HP-granulite facies metamorphism in mafic rocks at Sierra de Umango, Argentina: relics of subducted ophiolite complex in western Gondwana? In: Pankhurst, R.J., Veiga, G.D. (Eds.), Gondwana 12. Academia Nacional de Ciencias, Mendoza, Argentina, p. 178.

von Gosen, W., Buggish, W., Lehnert, O., 1995. Evolution of the southwestern Argentine Precordillera. Journal of South American Sciences 8, 377-404.

von Gosen, W., 1992. Structural evolution of the Argentine Precordillera: the Rio San Juan section. Journal of Structural Geology 14, 643-667.

von Gosen, W., 1995. Polyphase structural evolution of the southwestern Argentine Precordillera. Journal of South American Earth Sciences 8, 377-404.

von Gosen, W., 1997. Early Paleozoic and Andean structural evolution in the Rio Jáchal section of the Argentine Precordillera. Journal of South American Earth Sciences 10, 361-388.

von Gosen, W., 1998. Transpressive deformation in the south western part of the Sierra de San Luis (Sierras Pampeanas, Argentina). Journal of South American Earth Sciences 11, 233-264.

Hausen, H., 1921. On the lithology and geological structure of the Sierra de Umango Area, Province of La Rioja, Argentine Republic. Acta Academiae Aboensis, Mathematica et Physica I 4, 1-138.

Howell, D.G., 1989. Tectonics of Suspect Terranes. Mountain Building and Continental Growth. Chapman \& Hall, London, UK.

Jones, D.L., Howell, D.G., Coney, P.J., Monger, J.W.H., 1983. Recognition, character and analysis of tectonostratigraphic terranes in Western North America. In: Hashimoto, M., Uyeda, S. (Eds.), Accrection Tectonics in the Circum-Pacific Regions. Terrapub, Tokyo, pp. 21-35.

Jordan, T.E., Isacks, B.L., Almendinger, R.W., Brewer, J.A., Ramos, V.A., Ando, C.J., 1983. Andean tectonics related to geometry of subducted Nazca plate. Geological Society of America Bulletin 94, 341-361.

Jordan, T.E., Allmendinger, R.W., Damanti, J.F., Drake, R.E., 1993. Chronology of motion in a Complete Thrust Belt: the Precordillera, $30-31^{\circ} \mathrm{S}$, Andean Mountains. The Journal of Geology 101, 135-156.

Keller, M., Buggish, W., Lehnert, O., 1998. The stratigraphic record of the Argentine Precordillera and its plate tectonic background. In: Pankhurst, R.J., Rapela, C.W. (Eds.), The Proto-Andean Margin of Gondwana. Special Publication of the Geological Society of London, vol. 142, pp. 35-56.

Keller, M., 1999. Argentine Precordillera: sedimentary and plate tectonic history of a Laurentian crustal fragment in South America. Geological Society of America Special Paper 341, 131.

Kilmurray, J.O., Dalla Salda, L., 1971. Las fases de deformación y metamorfismo en la sierra de Maz, provincia de La Rioja, República Argentina. Revista de la Asociación Geológica Argentina 26, 245-263.

Kilmurray, J.O., Iñiguez Rodriguez, M., 1968. Los gneises escapolíticos de Las Ramaditas, Villa Unión (Provincia de La Rioja). Revista del Museo de La Plata 7, $13-29$.

Kilmurray, J.O., 1969. Petrología de las rocas metamórficas del sector noreste de la sierra de Maz, Villa Unión, Provincia de La Rioja. In: IV Jornadas Geológicas Argentinas, vol. 1, pp. 409-428.

Kilmurray, J.O. 1970. Las facies de metamorfismo en la Sierra de Maz, Provincia de La Rioja, República Argentina. Revista de la Asociacón Argentina de Mineralogía, Petrología y Sedimentología 1, 57-70. 
Kilmurray, J.O., 1971. Las ortoanfibolitas de la Sierra de Maz, Provincia de La Rioja. Revista del Museo de La Plata 7, 51-146.

Le Corre, C.A., Rossello, E.A., 1994. Kinematics of early Paleozoic ductile deformation in the basement of NW Argentina. Journal of South American Earth Sciences 7, 301-308.

Limarino, C.O., Césari, S.N., Net, L.I., Marenssi, S.A., Gutierrez, R.P., Tripaldia, A., 2002. The Upper Carboniferous postglacial transgression in the Paganzo and Rio Blanco basins (northwerstn Argentina): facies and stratigraphic significance. Journal of South American Earth Sciences 15, 445-460.

Martina, F., Astini, R.A., 2009. Geología de la región del Río Bonete en el antepaís andino $\left(27^{\circ} 30^{\prime} \mathrm{LS}\right)$ : extremo norte del terreno de Precordillera. Revista de la Asociación Geológica Argentina 64, 312-328.

Martino, R.D., 2003. Las fajas de deformación dúctil de las Sierras Pampeanas de Córdoba: una reseña general. Revista de la Asociación Geológica Argentina 58, 549-571.

McClay, K.R., Price, N.J. (Eds.), Thrust and Nappe Tectonics. Special Publication of the Geological Society of London, vol. 9, 539 pp.

Meira, V.T., 2010. Evolução estrutural da Sierra de Umango, Sierras Pampeanas Ocidentais, Noroeste da Argentina. Unpublished Master Dissertation, Universidade de São Paulo, 104 p.

Mulcahy, S.M., Roeske, S.M., McClelland, W.C., Jourdan, F., Iriondo, A., Renne, P.R., Vervoort, G.D., Vujovich, G.I., 2011. Structural evolution of a composite middle to lower crustal section: the Sierra de Pie de Palo, northwest Argentina. Tectonics 30, TC1005. doi:10.1029/2009TC002656.

Naipauer, M., Vujovich, G.I., Cingolani, C.A., McClelland, W.C., 2010. Detrital zircon analysis from the Neoproterozoic-Cambrian sedimentary cover (Cuyania terrane), Sierra de Pie de Palo, Argentina: evidence of a rift and passive margin system? Journal of South American Earth Sciences 29, 306-326.

Pankhurst, R.J., Rapela, C.W., 1998. The proto-Andean margin of Gondwana: an introduction. In: Pankhurst, R.J., Rapela, C.W. (Eds.), The Proto-Andean Margin of Gondwana. Special Publication of the Geological Society of London, vol. 142, pp. $1-9$.

Paterson, S.R., Vernon, R.H., Tobisch, O.T., 1989. A review of criteria for the identification of magmatic and tectonic foliations in granitoids. Journal of Structural Geology 11, 349-363.

Porcher, C.C., Fernandes, L.A.D., Vujovich, G.I., Chernicoff, C.J., 2004. Thermobarometry, $\mathrm{Sm} / \mathrm{Nd}$ ages and geophysical evidence for location of the suture zone between Cuyania and the Western Proto-Andean Margin of Gondwana. Gondwana Research 7, 1057-1076.

Quernadelle, S., Ramos, V.A., 1999. The Ordovician western Sierras Pampeanas magmatic belt: record of Precordillera accretion in Argentina. In: Ramos, V.A. Keppie, J.D. (Eds.), Laurentia Gondwana Connections before Pangea. Geological Society of America, Special Paper, vol. 336, pp. 63-86.

Ramos, V.A., Aleman, A., 2000. Tectonic evolution of the Andes. In: Cordani, U.G., Milani, E.J., Thomaz Filho, A., Campos, D.A. (Eds.), Tectonic Evolution of South America, pp. 635-685.

Ramos, V.A., Jordan, T., Allmendinger, R.W., Kay, S.M., Cortés, J.M., Palma, M.A., 1984 Chilenia: Un terreno alóctono en la evolución paleozoica de los Andes Centrales. In: IX Congreso Geológico Argentino, vol. 2, pp. 84-106.

Ramos, V.A., Jordan, T.E., Allmendinger, R.W., Mpodozis, C., Kay, S.M., Cortés, J.M., Palma, M.A., 1986. Paleozoic terranes of the central Argentine-Chilean Andes. Tectonics 5, 855-880.

Ramos, V.A., Vujovich, G.I., Dallmeyer, R.D., 1996. Los klippes y ventanas tectónicas preándicas de la Sierra de Pie de Palo (San Juan): edad y implicaciones tectónicas. In: XIII Congreso Geológico Argentino and III Congreso de Exploración de Hidrocarbunos, vol. 5, pp. 377-391.

Ramos, V.A., Dallmeyer, R.D., Vujovich, G.I., 1998. Time constraints on the Early Paleozoic docking of the Precordillera, central Argentina. In: Pankhurst, R.J., Rapela, C.W. (Eds.), The Proto-Andean Margin of Gondwana. Special Publication of the Geological Society of London, vol. 142, pp. 143-158.

Ramos, V.A., Cristallini, E.O., Pérez, D.J., 2002. The Pampean flat-slab of the Central Andes. Journal of South American Earth Sciences 15, 59-78.

Ramos, V.A., 1988a. Tectonics of the Late Proterozoic-Early Paleozoic: a collisional history of southern South America. Episodes 11, 168-174.

Ramos, V.A., 1988b. The tectonics of the Central Andes: $30^{\circ}-33^{\circ} \mathrm{S}$ latitude. In: Clark, S., Burchfiel, D., Suppe, J. (Eds.), Processes in Continental Lithospheric Deformation. Geological Society of America, Special Paper, vol. 218, pp. 31-54.

Ramos, V.A., 1999a. Plate tectonic setting of the Andean Cordillera. Episodes 22, $183-189$.

Ramos, V.A., 1999b. Rasgos estructurales del territorio Argentino. In: Caminos, R. (Ed.), Geologia Argentina. Servicio Geológico Minero Argentino, Anais, vol. 29, pp. 715-784.

Ramos, V.A., 1999c. Los depósitos sinorogénicos terciarios de la región Andina. In: Caminos, R. (Ed.), Geologia Argentina. Servicio Geológico Minero Argentino, Anais, vol. 29, pp. 651-682.

Ramos, V.A., 2004. Cuyania, an exotic block to Gondwana: review of a historical success and the present problems. Gondwana Research 7, 1009-1026.

Ramos, V.A., 2008. The basement of the Central Andes: the Arequipa and related terranes. Annual Review of Earth and Planetary Sciences 36, 1-43.
Rapela, C.W., Pankhurst, R.J., Casquet, C., Baldo, E., Saavedra, J., Galindo, C. Fanning, C.M., 1998. The Pampean Orogeny of the southern proto-Andes: Cambrian continental collision in the Sierras de Córdoba. In: Pankhurst, R.J., Rapela, C.W. (Eds.), The Proto-Andean Margin of Gondwana. Special Publication of the Geological Society of London, vol. 142, pp. 181-217.

Rapela, C.W., Pankhurst, R.J., Casquet, C., Baldo, E., Galindo, C., Fanning, C.M. Dahlquist, J.M., 2010. The Western Sierras Pampeanas: protracted Grenville-age history (1330-1030 Ma) of intra-oceanic arcs, subduction-accretion at continental edge and AMCG intraplate magmatism. Journal of South American Earth Sciences 29, 105-127.

Sato, A.M., Tickyj, H., Llambiás, E.J., Sato, K., 2000. The Las Matras tonalitictrondhjemitic pluton, central Argentina: Grenvillian-age constraints, geochemical characteristics, and regional implications. Journal of South American Earth Sciences 13, 587-610.

Sato, A.M., Tickyj, H., Llambiás, E.J., Basei, M.A.S., González, P.D., 2004. Las Matras Block, Central Argentina $\left(37^{\circ} \mathrm{S}-67^{\circ} \mathrm{W}\right)$ : the southernmost Cuyania terrane and its relationship with the Famatinian Orogeny. Gondwana Research 7, 1077-1087.

Simpson, C., Law, R.D., Gromet, L.P., Miro, R., Northrup, C.J., 2003. Paleozoic deformation in the Sierras de Córdoba and Sierra de Las Minas, eastern Sierras Pampeanas, Argentina. Journal of South American Earth Sciences 13, 749-764.

van Staal, C.R., Vujovich, G.I., Currie, K.L., Naipauer, M., 2011. An Alpine-style Ordovician collision complex in the Sierra de Pie de Palo, Argentina: Record of subduction of Cuyania beneath Famatina arc. Journal of Structural Geology 33, 343-361.

Thomas, W.A., Astini, R.A., 2003. Ordovician accretion of the Argentine Precordillera terrane to Gondwana: a review. Journal of South American Earth Sciences 16, 67-79.

Thomas, W.A., Astini, R.A., 2007. Vestiges of an Ordovician west-vergent thinskinned Ocloyic thrust belt in the Argentine Precordillera, southern Central Andes. Journal of Structural Geology 29, 1369-1385.

Turner, J.C.M., 1964. Descripción geológica de la Hoja 15c, Vinchina. Boletín de la Dirección Nacional de Geología y Minería 100, 1-86.

Varela, R., López de Luchi, M., Cingolani, C., Dallas Salda, L., 1996. Geocronología de gneises y granitoides de la Sierra de Umango, La Rioja. Implicancias tectónicas. In: XIII Congreso Geológico Argentino and III Congreso de Exploración de Hidrocarburos, vol. 3, pp. 519-527.

Varela, R., Roverano, D., Sato, A.M., 2000. Granito El Peñón, sierra de Umango: descripción, edad $\mathrm{Rb} / \mathrm{Sr}$ e implicancias geotectónicas. Revista de la Asociación Geológica Argentina 55, 407-413.

Varela, R., Valencio, S.A., Ramos, A.M., Sato, K., González, P.D., Panarello, H.O., Roverano, D.R., 2001. Isotopic Strontium, Carbon and Oxygen study on Neoproterozoic marbles from sierra de Umango, Andean Foreland, Argentina. In: III South American Symposium on Isotope Geology, Revista Comunicaciones (52: 121, CD Sociedad Geologica Chilena). pp. 450-453.

Varela, R., Sato, A.M., González, P.D., 2002. Metamorfismo y deformación Devónicos en la Sierra de Umango, Sierras Pampeanas Occidentales, La Rioja, Argentina. In XV Congreso Geológico Argentino, vol. 2, pp. 57-63.

Varela, R., Sato, A.M., Basei, M.A.S., Siga Jr., O., 2003a. Proterozoico medio y Paleozoico inferior de la Sierra de Umango, Antepaís Andino (29 $\mathrm{S})$, Argentina. Edades U/Pb y caracterizaciones isotópicas. Revista Geologica do Chile 30, 265-284.

Varela, R., Basei, M.A.S., Sato, A.M., González, P.D., Siga JR.O., Campos Neto, M.C. Cingolani, C.A., 2003b. Grevillian basement and famatinian events of the Sierra de Umango $\left(29^{\circ} \mathrm{S}\right)$ : a review and new geochronogical data. In: IV South American Symposium on Isotope Geology, Short Papers.

Varela, R., Basei, M.A.S., Sato, A.M., Passarelli, C.R., Cingolani, C.A., González, P.D., 2005. Edades U/Pb y Rb-Sr del Granito Los Guandacolinos, sierra de Umango, La Rioja. Implicancias tectónicas. In: XVI Congreso Geológico Argentino, vol. 1, pp. 109-116.

Varela, R., Basei, M.A.S., Sato, A.M., González, P.D., Siga JR., O., Campos Neto, M.C., Cingolani, C.A., 2008. New O-Pb data for Sierra de Umango, Andean Foreland at $29^{\circ} \mathrm{S}$ and geodadynamic implications. In: VI South American Symposium on Isotope Geology. Short Papers.

Varela, R., Basei, M.A.S., González, P.D., Sato, A.M., Naipauer, M., Campos Neto, M.C. Cingolani, C.A., Meira, V.T., 2011. Accretion of Grenvillian terranes to the west of the Rio de la Plata craton, western Argentina. International Journal of Earth Sciences 100, 243-272. doi:10.1007/s00531-010-0614-2.

Voldman, G.G., Albanesi, G.L., Ramos, V.A., 2008. Ordovician metamorphic event in the carbonate platform of the Argentine Precordillera: implications for the geotectonic evolution of the proto-Andean margin of Gondwana. Geology 37, $311-314$.

Vujovich, G.I., Kay, S.M., 1998. A Laurentian? Grenville-age oceanic arc/back-arc terrane in the Sierra de Pie de Palo, Western Sierras Pampeanas, Argentina. In: Pankhurst, R.J., Rapela, C.W. (Eds.), The Proto-Andean Margin of Gondwana. Special Publication of the Geological Society of London, vol. 142, pp. 159-180.

Vujovich, G.I., Van Staal, C.R., Davis, W., 2004. Age constraints on the tectonic evolution and provenance of the Pie de Palo Complex, Cuyania composite terrane, and the Famatinian orogeny in the Sierra de Pie de Palo, San Juan, Argentina. Gondwana Research 7, 1041-1056. 